\title{
La Asamblea Constituyente de Asalariados e Intelectuales Chile, 1925: entre el olvido y la mitificación*
}

\author{
The Constituent Assembly of Workers and Intellectuals, \\ Chile, 1925: among oblivion and mythologization
}

\author{
Sergio Grez Toso**
}

\begin{abstract}
Resumen: Este artículo aborda la breve historia de la Asamblea Constituyente de Asalariados e Intelectuales o "Constituyente Chica", que tuvo lugar en Santiago de Chile entre el 8 y el 11 de marzo de 1925, en vísperas del proceso constituyente anunciado por el gobierno. Esta deliberación impulsada por iniciativa de un amplio abanico de organizaciones del movimiento popular -Partido Comunista, Federación Obrera de Chile, Asociación General de Profesores, Unión de Empleados de Chile, Federación de Estudiantes de Chile, sindicalistas independientes, sectores anarquistas, demócratas, radicales, feministas y otros- fue prontamente superada por la imposición del itinerario constituyente oficial del presidente Arturo Alessandri Palma. Con similar rapidez, los promotores de la "Constituyente Chica" borraron de sus memorias colectivas esta experiencia, generando las condiciones para su silenciamiento o minimización por parte de los historiadores especializados en dicho período. En las antípodas del olvido y de la minimización, más recientemente, esta reflexión de los sectores populares organizados ha sido presentada de manera mitificada como un ejercicio de poder constituyente de "bases sociales" absolutamente autónomas, sin vínculo con los referentes políticos presentes en el movimiento popular. Frente a ambos extremos que se manifiestan en la memoria colectiva y en la historiografía, el autor de este artículo reconstruye el contexto en que surgió la Asamblea Constituyente de Asalariados e Intelectuales, su génesis, desarrollo y desenlace, a fin de acercarnos, en base a un amplio abanico de fuentes, a una visión más equilibrada y objetiva, en definitiva, más cercana a la verdad histórica.
\end{abstract}

Palabras claves: Chile - Asamblea Constituyente de Asalariados e Intelectuales Constituyente Chica - Movimiento popular

\begin{abstract}
The following article deals with the brief history of the Constituent Assembly of Workers and Intellectuals or "Small Constituent" that took place in Santiago de Chile between March $8^{\text {th }}$ and $11^{\text {th }}, 1925$, days before the constituent process announced by the government took place. Said deliberation, driven by the initiative of a wide variety of organizations of the Popular Movement (Communist Party, Federation of Chilean Workers, General Association of Teachers, Union of Chilean Employees, Federation of Chilean Students, anarchist sectors, democrats,
\end{abstract}

\footnotetext{
* Artículo elaborado en el marco del Proyecto FONDECYT No1130286 de la Comisión Nacional de Investigación Científica y Tecnológica de Chile (CONICYT). Se agradece la colaboración de Ximena Urtubia Odekerken y Patricia Ayala Apablaza.

** Dr. en Historia. Académico de la Universidad de Chile. Correo electrónico: sergiogreztoso@ gmail.com
} 
radicals and feminists, among others) came promptly to an end due to the imposition of the official constituent itinerary of president Arturo Alessandri Palma. In a similar fashion, the promoters of the "Small Constituent" erased the experience from their collective memory, paving the way for its silencing or minimization by historians that specialize in said period of time. Recently, contrary to forgetting and minimizing, this reflection lead by organized popular sectors has been presented in a mythified fashion as a constituent power exercise of completely autonomous "social bases", without any link to the political models present in the Popular Movement. Facing both opposite ends that show up in the collective memory and in historiography, the author of this article reconstructs the context in which the Constituent Assembly of Workers and Intellectuals sprang forth, its conception, development and outcome, to bring us closer, based on a wide variety of sources, to a more balanced and objective point of view, that is to say, closer to the historic truth.

Key Words: Chile, Constituent Assembly of Workers and Intellectuals, Small Constituent, Popular Movement.

Recibido: 18 mayo 2016

Aceptado: 27 julio 2016

\section{Introducción}

La Asamblea Constituyente de Asalariados e Intelectuales que tuvo lugar en Santiago de Chile en marzo de 1925, conocida también por el sobrenombre de "Constituyente Chica" puesto por sus propios promotores, es un buen ejemplo de la complejidad de la memoria humana y de los usos políticos de la Historia o disciplina historiográfica. La corta duración de este evento -cuatro días de encendidos debates en un teatro de la capital- y la vertiginosa evolución de la situación política del país durante el otoño e invierno de aquel año, hicieron que dicha deliberación, destinada a aunar los propósitos de los trabajadores e intelectuales de avanzada en la perspectiva de un incipiente proceso constituyente, tempranamente dejara de tener alguna viabilidad práctica y fuera borrada con facilidad de la memoria de las fuerzas sociales y políticas que la impulsaron.

Al cabo de cuatro meses de culminados los trabajos de los delegados de esta convención popular, la promesa de Asamblea Constituyente hecha por el presidente de la República Arturo Alessandri Palma fue desechada por el mismo mandatario al nombrar una comisión encargada de redactar un proyecto de Constitución. Seis meses después de la realización de la "Constituyente Chica", la vía plebiscitaria impuesta por "el León" sancionó la Carta Magna prohijada por este personaje, sepultando las esperanzas de génesis democrática de una nueva Constitución mediante una Asamblea Constituyente. De la deliberación efectuada por los activistas del mundo laboral y los intelectuales más progresistas solo quedó un efímero recuerdo. Las necesidades de las luchas del momento, el flamante marco institucional y nuevos problemas planteados a la sociedad sepultaron la experiencia de la Constituyente popular, desterrándola incluso de la memoria del movimiento que la engendró. 
Desde entonces, ninguno de los actores del ejercicio constituyente de marzo de 1925 reivindicó dicha iniciativa. Como ocurre muchas veces, los historiadores recorrieron la misma senda de la memoria social. La "Constituyente Chica" fue ignorada o apenas mencionada en la mayoría de las obras generales sobre el período. Durante décadas ningún investigador estimó que fuese necesario poner atención a este hecho.

No es extraño. En la historia pasa a menudo que ciertos episodios que en su momento tuvieron una repercusión indiscutible, muy pronto son cubiertos por el manto del olvido, no necesariamente por acción premeditada de poderes interesados en su ocultamiento ni por tratarse de hechos traumáticos que los propios sujetos afectados, sus comunidades y descendientes prefieren no recordar. Ello sucede porque tanto la memoria individual como la social son selectivas, no pueden recordarlo todo. Este olvido constituyente, inevitable, sano -sostiene el historiador gallego José Carlos Bermejo Barrera"es el anverso del mecanismo selectivo del recuerdo" y funciona en todos los casos. Su naturaleza es intencional, "ya que va unido a la voluntad de asunción de un recuerdo, y no de otro, pero no posee un componente represivo"1.

Como ya hemos dicho, en este caso la historiografía -salvo excepciones- siguió las aguas de la memoria social. Aunque a diferencia del olvido constituyente de esta, la omisión de los historiadores podría ser considerada como un olvido excluyente, selectivo en sentido negativo, aquel que "no excluye porque se quiera recordar otra cosa" sino porque, ante todo "su voluntad es la de excluir, no la de recordar": olvido que implanta una censura porque desea reprimir un contenido a fin de controlarlo. El olvido excluyente, precisa Bermejo Barrera, "arroja fuera del mundo de lo decible, más allá de los límites de la palabra, aquello que no puede ser asumido no solo positiva sino tampoco negativamente"2.

¿Qué es lo no decible de la experiencia frustrada de la "Constituyente Chica"? Su propia existencia, el esfuerzo del movimiento popular en Chile por erigirse en actor de un proceso constituyente por primera vez al cabo de cien años de historia republicana. Situación inédita, intolerable para la clase dominante incluso un siglo más tarde ${ }^{3}$.

No fue hasta casi sesenta años después de su realización que el historiador comunista Hernán Ramírez Necochea le dedicó unas cuantas páginas de su libro Origen y formación del Partido Comunista de Chile ${ }^{4}$. No obstante, al examinar los pasajes de su obra consagrados a este tema, se constata que más que ser el resultado de una investigación acuciosa, fueron escritos como balance general del período, en base a pocas fuentes y en tono de reproche al "infantilismo revolucionario" y al "reformismo" que habría impregnado buena parte de la política de su propio partido a mediados de la década de 1920. La idea de llevar adelante un Congreso de Asalariados e Intelectuales destinado a concretar en un

\footnotetext{
${ }^{1}$ José Carlos Bermejo Barrera, "La Historia, la memoria y el olvido", en José Carlos Bermejo Barrera y Pedro Andrés Piedras Monroy, Genealogía de la Historia. Ensayos de Historia Teórica III, Madrid, Ediciones Akal, 1999, pág, 195.

2 Ibid., pág. 195.

${ }^{3}$ Sergio Grez Toso, "La ausencia de un poder constituyente democrático en la historia de Chile", en Sergio Grez y Foro por la Asamblea Constituyente, Asamblea Constituyente. La alternativa democrática para Chile, Santiago, Editorial América en Movimiento, 2016, 2a edición, págs. 19-53.

${ }^{4}$ Hernán Ramírez Necochea, Origen y formación del Partido Comunista de Chile. Ensayo de historia política y social de Chile, en Hernán Ramírez Necochea, Obras escogidas, vol. II, Santiago, Lom Ediciones, 2007. La primera edición de esta obra es de Moscú, Editorial Progreso, 1984.
} 
proyecto de Constitución Política las aspiraciones populares, formulada a fines de enero de 1925 por el Comité Nacional Obrero -suerte de Frente Amplio de organizaciones sociales y políticas creado por iniciativa del Partido Comunista (PCCh) y la Federación Obrera de Chile $(\mathrm{FOCH})$ pocos días después del golpe de Estado del 23 del mismo mes consumado por los militares jóvenes de acendrado espíritu reformista- fue catalogada por Ramírez Necochea como una expresión de desviaciones de "izquierda" y de "derecha" en el seno del comunismo chileno. De "izquierda", puesto que dicha propuesta revelaba -según su interpretación- la estimación errónea "que había caducado el régimen burgués y que las fuerzas político sociales de la burguesía estaban desmanteladas, motivo por el cual era factible un Congreso Constituyente de Asalariados e Intelectuales, que tomara la tarea de dar al país un nuevo ordenamiento constitucional"5. De "derecha", ya que "paradójicamente, esa proposición no era base para que el movimiento obrero operara independientemente; era formulada a la oficialidad del ejército, lo que dejaba abierta la posibilidad para que esta, en acuerdo con las fuerzas burguesas a que estaba vinculada, las desestimara, como en efecto sucedió"6 . Esto demostraría, según este autor, la contradicción en que habrían incurrido los comunistas por haber confiado, por un lado, "en la posibilidad de que el movimiento obrero cumpliera solo su tarea revolucionaria, mientras, por otro lado, tendían a subordinar la actividad revolucionaria del proletariado a los oficiales de las Fuerzas Armadas", cuestión "reveladora de la confusión política que dominaba a quienes se situaban en posiciones infantilmente revolucionarias", . Las resoluciones adoptadas por la "Constituyente Chica" también fueron consideradas por Ramírez Necochea como una expresión del "izquierdismo" en el seno del PCCh puesto que estas -como preconizar "lisa y llanamente una Constitución socialista muy curiosa, en que se omitía la dictadura del proletariado", planteándose, entre otras cosas, que el Poder Legislativo residiría en una "Cámara Funcional" cuyos miembros serían elegidos por los gremios organizadossignificaban actuar "como si Chile hubiese estado en la víspera misma de la conquista del poder por la clase obrera". Por estas razones, y por haber marginado de ella la presencia partidaria incluyendo al propio $\mathrm{PCCh}$, aceptando solamente representantes gremiales, por su acelerada preparación "sin que se diera tiempo para agitar a las masas en torno a las proposiciones que en ella se formularían", Ramírez Necochea estimó que "tanto en su gestación y composición, como en su desarrollo y resoluciones, la Asamblea Constituyente de Obreros e Intelectuales es un ejemplo típico de infantilismo revolucionario, mezclado con modalidades de reformismo que de él derivan lógicamente", sentenciando que "fue convertida así en algo intrascendente, que no ejerció ni la menor influencia en los acontecimientos de 1925, que no encontró resonancia en la clase obrera y que incluso para el Partido [Comunista] careció de valor". Peor aún, con la promoción de tal organismo, concluyó la voz historiográfica más autorizada del PCCh, "se llevó a cabo una acción puramente formal, que inhabilitó al Partido y a la clase obrera para tener una participación más activa y decisiva en la nueva Ley Fundamental del país; de hecho, esta misión quedó

\footnotetext{
${ }^{5}$ Ramírez Necochea, op. cit., pág. 350.

${ }^{6}$ Ibid., pág. 351.

${ }^{7}$ Ibid.
} 
confiada exclusivamente a la burguesía, que hizo e impuso de manera irregular la Constitución de $1925^{\prime \prime}$.

La visión de Ramírez Necochea sobre la iniciativa impulsada por sus correligionarios en 1925 es pues, lapidaria. La "Constituyente Chica" no solo habría sido intrascendente sino nociva pues sus erróneas concepciones habrían contribuido a anular por completo la capacidad de la clase obrera y del PCCh de incidir en el proceso constituyente encabezado por Arturo Alessandri y las fuerzas burguesas que lo apoyaban.

Aun parezca un contrasentido, la Asamblea Constituyente de Asalariados e Intelectuales fue más valorada por un historiador de reconocida cepa conservadora, Gonzalo Vial Correa, que por el historiador comunista Ramírez Necochea. Vial reconoció en la heterogénea composición popular y mesocrática de este ejercicio deliberativo, al menos la cualidad de ser representativa de fuerzas sociales emergentes aptas para formular proyectos innovadores: "Tan abigarrado conjunto tenía un mérito, en cierto modo el signo de los tiempos: era gente popular o de clase media, de audaces ideas político-sociales e indudable capacidad intelectual"9. Otros historiadores -incluidos algunos como Luis Vitale y Andrew Barnad sobre quienes no podría recaer la más leve sospecha de animosidad ideológica- si bien se refirieron a ella, no la destacaron como un hecho relevante ni formularon juicios de valor. Vitale se limitó a narrar de forma escueta su preparación y realización sin emitir comentarios ni realizar un esfuerzo interpretativo ${ }^{10}$. De manera aún más sucinta, en unas pocas líneas de su tesis doctoral consagrada al PCCh, Barnard dio cuenta del involucramiento del PCCh en la formación del Comité Nacional Obrero y su llamamiento a una Constituyente propia, la "Constituyente Chica", señalando que esta tuvo poca o nula influencia en la gestación de la Constitución de $1925^{11}$.

En las antípodas de la interpretación de Ramírez Necochea se encuentra la exégesis de Gabriel Salazar. Una de sus primeras aproximaciones al tema se plasmó en un breve documento de trabajo publicado en 1992, en el cual inscribió la experiencia de la Constituyente de Asalariados e Intelectuales en el contexto de la crisis del sistema liberal y del ascenso de la lucha popular desde la Asamblea Obrera de Alimentación Nacional (AOAN) en 1918 y 1919, explicando el proyecto que se cristalizaría en la deliberación de marzo de 1925 como resultado de una acción espontánea y autónoma de "las bases sociales", sin presencia significativa de partidos ni militantes. Luego del golpe de Estado del 23 de enero de ese año, asevera Salazar, "las bases no esperaron. Simplemente, entre

\footnotetext{
${ }^{8}$ Ibid., págs. 352 y 353. Cabe señalar que otro historiador comunista, Iván Ljubetic, una generación posterior a Ramírez Necochea, no se refirió a la "Constituyente Chica", Iván Ljubetic Vargas, Breve Historia del Partido Comunista, [Santiago], Editorial La Colmena, sin fecha. Similar omisión encontramos en el historiador trotskista Nicolás Miranda, Historia Marxista del Partido Comunista de Chile, Santiago, Ediciones Clase contra Clase, 2001.

${ }^{9}$ Gonzalo Vial, Historia de Chile (1891-1973), vol. III, Arturo Alessandri y los golpes militares (1920-1925), Santiago, Empresa Editora Zig-Zag S.A., 2008, pág. 533.

${ }^{10}$ Luis Vitale, Interpretación marxista de la Historia de Chile, tomo V. De la República Parlamentaria a la República Socialista. De la dependencia inglesa a la norteamericana (1891-1932), Santiago, Lom Ediciones, sin fecha, págs. 297 y 298.

${ }^{11}$ Véase también, Andrew Barnard, The Chilean Communist Party, 1922-1947, thesis present for the degree of Doctor of Philosophy in the University of London, London, University College, University of London, december 1977, págs. 86-88.
} 
enero y marzo, se autoconvocaron, prepararon y autoerigieron en Asamblea Constituyente. Las bases aprendían rápido las enseñanzas de la historia",12.

Aparte el hecho de que, como demostraremos, las bases no se autoerigieron en Asamblea Constituyente porque siempre se planteó que la "Constituyente Chica" era un mero ejercicio previo a la Asamblea Nacional Constituyente, llama la atención en este trabajo la ausencia de referencias a los partidos y militantes: el historiador Salazar no indica ni los nombres ni la filiación partidaria de los gestores de la iniciativa. Por ejemplo, se refiere sin más señas a quien encabezaba el organismo promotor de la Asamblea Constituyente de Asalariados e Intelectuales como el presidente del Comité Nacional Obrero, sin precisar que se trataba de Manuel Hidalgo, uno de los principales dirigentes comunistas, tampoco identifica a los restantes miembros de esa entidad, y cuando se refiere al periódico Justicia, autodefinido en la primera página de todas sus ediciones como órgano oficial de la FOCH y del PCCh, Salazar lo cataloga sencillamente como "un diario obrero" " Con posterioridad, el profesor Salazar incursionó con mayor profundidad en este tema $^{14}$. A partir de una base empírica mucho más extensa, reiteró su lectura de la "Constituyente Chica" como obra de "las bases sociales", las "bases ciudadanas" o, de un modo más lacónico, "las bases", en tanto generadoras y ejecutoras de este ejercicio deliberativo, con menciones tangenciales a las fuerzas políticas que la impulsaron, debatieron y se enfrentaron en su seno. Aunque esta vez identificó a numerosos participantes en el Comité Nacional Obrero y en la asamblea del pueblo de marzo de 1925, volvió a omitir las militancias partidarias de casi todos ellos, presentándolos como simples ciudadanos y ciudadanas o líderes sociales desvinculados de las colectividades políticas, diciendo a lo sumo, que numerosos representantes de la FOCH eran militantes del $\mathrm{PCCh}^{15}$ y que estos se enfrentaron en algunas discusiones con otros delegados a la "Constituyente Chica", en su mayoría, profesores y estudiantes ${ }^{16}$. Según esta visión, la Asamblea Constituyente de Asalariados e Intelectuales sería la máxima expresión de autonomía, espontaneidad y ejercicio del "poder constituyente" de las "bases sociales" en la historia de Chile, bases libres casi por completo de interferencias partidarias e ideológicas ajenas a su propia y directa práctica social. Si sus objetivos -sobre todo el proyecto de "cámaras funcionales"- se hubiesen concretado, sostiene Salazar, ello habría significado la "cesantía histórica" de los políticos profesionales, de sus partidos y del sistema político liberal ${ }^{17}$.

\footnotetext{
${ }^{12}$ Gabriel Salazar V., "Movimiento social y construcción de Estado: la Asamblea Constituyente popular de 1925”, Documento de Trabajo N¹33, Santiago, SUR, Centro de Estudios Sociales y Educación, 1992, pág. 10. Las cursivas son nuestras.

${ }^{13}$ Ibid., pág. 11.

${ }^{14}$ Gabriel Salazar V., Del poder constituyente de asalariados e intelectuales (Chile, siglos XX y XXI), Santiago, Lom Ediciones, 2009.

${ }^{15}$ Ibid., pág. 86.

${ }^{16}$ Ibid., págs. 76-88.

17 Ibid., págs. 90-92. En un libro manifiesto publicado con posterioridad, este autor radicalizó sus apreciaciones respecto del nivel de participación de los militantes en la "Constituyente Chica", afirmando que se trató de "una Asamblea estrictamente popular (trabajadores, estudiantes, profesores y profesionales, con exclusión categórica de militares, militantes de partido y mercaderes-banqueros), en preparación a la Asamblea Nacional Constituyente, que debía ser convocada próximamente", Gabriel Salazar, En el nombre del poder popular constituyente (Chile, siglo XXI), Santiago, Lom Ediciones, 2011, pág. 69.
} 
El contraste entre ambas interpretaciones es patente. Mientras que para Ramírez Necochea la "Constituyente Chica" habría sido una manifestación de la inmadurez del joven PCCh, expresada en desviaciones de "izquierda" y de "derecha", experiencia intrascendente y digna solo de ser recordada como ejemplo negativo a no ser repetido; para Salazar esta iniciativa se alza como el paradigma del poder constituyente autónomo, sin relación alguna con las fuerzas políticas preexistentes, aquel poder "que puede y debe ejercer el pueblo por sí mismo -en tanto que ciudadanía soberana- para construir, según su voluntad deliberada y libremente expresada, el Estado (junto al Mercado y la Sociedad Civil) que le parezca necesario y conveniente para su desarrollo y bienestar"18.

El olvido, los silencios, el desprecio, los anatemas, la minimización y la mitificación que se manifiestan en la memoria colectiva y en la historiografía, nos obligan a recorrer la breve historia de la "Constituyente Chica" -el contexto en que surgió, su génesis, desarrollo y desenlace- a fin de acercarnos, en base al fundamento de nuestra disciplina y los datos que emanan de las fuentes, a una visión más equilibrada y objetiva, en definitiva, más cercana a la verdad ${ }^{19}$.

\section{Los orígenes del proceso constituyente}

La irrupción del estamento militar en la política nacional a comienzos de septiembre de 1924 provocó la salida de Alessandri del cargo de presidente de la República, su partida voluntaria al exilio acogiéndose a una autorización constitucional otorgada por el Parlamento, además de la instauración de una Junta de Gobierno militar y la apertura de un proceso constituyente a raíz de la promesa formulada por los uniformados en su Manifiesto del 12 de septiembre de convocar a una Asamblea Constituyente. Este anuncio generó una amplia adhesión ciudadana debido al desprestigio del régimen parlamentario imperante desde 1891 y a la frustración de buena parte de las esperanzas del pueblo depositadas en el proyecto reformista del "León de Tarapacá". Los militares jóvenes que con su presión cortaron el nudo gordiano de la resistencia parlamentaria a las reformas sociales formuladas por el Jefe de Estado, concitaron gran simpatía con su proyecto de modernización, en especial al ofrecer la génesis de una Constitución mediante la vía más democrática, la Asamblea Constituyente. Aunque la idea de la "revisión completa" de la Constitución de 1833 estaba presente desde mucho antes en el seno del movimiento popular -el Partido Democrático la incluyó en sus programas desde inicios de siglo ${ }^{20}$ - dando lugar con el correr de los años a proposiciones más radicales que apuntaban al cambio completo de régimen constitucional, como el alentado por Recabarren y el Partido Obrero Socialista (POS), primero, y luego por su sucesor el PCCh, dichas propuestas no se habían traducido en un movimiento efectivo para el logro de ese objetivo. El quiebre institucional de septiembre de

\footnotetext{
${ }^{18}$ Salazar, En el nombre del poder..., op. cit., pág. 27. Cursivas en el original. Cf. con la reseña de Manuel Loyola T. publicada en Cuadernos de Historia, N³6, Santiago, junio de 2012, págs. 183-185.

19 Sobre realidad, verdad histórica y crítica al posmodernismo historiográfico, véase, entre otros, Adam Schaff, Historia y verdad, Barcelona, Editorial Crítica, 1983; Eric Hobsbawm, Sobre la historia, Barcelona, Crítica, 2002; Josep Fontana, La historia de los hombres: el siglo XX, Barcelona, Crítica, 2002.

20 "Manifiesto. El Directorio General a las agrupaciones del Partido Democrático i a la Democracia del país", Democracia, Santiago, 31 de agosto de 1902.
} 
1924 y las promesas de los militares pusieron el tema constitucional a la orden del día, generando reacciones encontradas en el movimiento popular.

Comunistas y fochistas oscilaron entre una benevolente y expectante neutralidad y la natural desconfianza que les inspiraba el sangriento historial de las Fuerzas Armadas de represión a los movimientos populares. No obstante, desde el primer momento entendieron que se abría una coyuntura en la que los trabajadores, por primera vez, podían hacer oír su voz en un proceso constituyente ${ }^{21}$. Al día siguiente del establecimiento definitivo de la Junta de Gobierno y del cierre del Congreso Nacional decretado por el nuevo poder Ejecutivo, el órgano comunista-fochista Justicia publicó un artículo en el que se proponía la convocatoria a una Asamblea Constituyente estructurada en base a representantes de fábricas o establecimientos industriales, mineros, salitreros, fundos, haciendas, puertos y otros, a razón de uno cada mil obreros o fracción, agrupando hasta alcanzar la cifra adecuada a las empresas que contaran con menos de quinientos trabajadores para elegir sus delegados. Igual método se aplicaría para elegir representantes del Ejército, la Armada y la Policía, de los comerciantes e industriales asociados. Similar derecho tendrían las direcciones centrales de las organizaciones obreras de cualquier tipo y las directivas de todos los partidos políticos ${ }^{22}$. Esta acabada propuesta comunista salía al paso a otras que ya empezaban a formular distintos sectores, en particular a una que pretendía dar veinte delegados a cada una de las distintas categorías socio profesionales: agricultores, profesionales, comerciantes y obreros, dejando a estos últimos en franca minoría ${ }^{23}$.

Aquel día los uniformados publicaron el Manifiesto de la Junta Militar al país en el que junto con justificar su intervención debido a los males que aquejaban a la nación, prometieron "abolir la política gangrenada", no eternizarse en el poder ni alzar a ningún caudillo, mantener las libertades públicas, convocar a "una libre Asamblea Constituyente" para elaborar una Constitución a la altura de las aspiraciones nacionales. Luego se elegirían poderes públicos, "sobre Registros hechos por inscripción amplia y libre". Constituidos esos poderes, los militares terminarían su misión ${ }^{24}$.

El 13 de septiembre, el líder del PCCh, Luis Emilio Recabarren publicó en la misma línea de sus camaradas de Justicia, un artículo de análisis más profundo en el cual junto con expresar la desconfianza que le suscitaban los militares, adhería a su Manifiesto y a la idea de una Asamblea Constituyente, sentando las bases de una táctica para los comunistas y fochistas en el nuevo contexto:

\footnotetext{
${ }^{21}$ Una exposición detallada de las reacciones y posicionamientos del PCCh y la FOCH frente a la instauración de la Junta Militar de gobierno y sus promesas en Sergio Grez Toso, Historia del comunismo en Chile. La era de Recabarren, 1912-1924, Santiago, Lom Ediciones, 2011, págs. 297-319. Véase también, Barnard, op. cit., págs. 62-64.

22 "Sería preferible convocar una Constituyente", Justicia, Santiago, 12 de septiembre de 1924. El mismo artículo se encuentra también en el periódico comunista El Despertar de los Trabajadores, Iquique, 23 de septiembre de 1924.

23 “¿Con qué elemento se pretende constituir la Asamblea Constituyente?”, La Jornada Comunista, Valdivia, 24 de septiembre de 1924.

24 "Manifiesto de la Junta Militar al país", Santiago, 12 de septiembre de 1924. Reproducido en Augusto Iglesias, Alessandri, una etapa de la democracia en América. Tiempo, vida, acción, Santiago, Editorial Andrés Bello, 1960, pág. 418.
} 
La Junta Militar declara que bajo el amparo de su fuerza entregará al país la creación de su nueva Constitución, para que en el porvenir, el pueblo, viva conforme a las nuevas leyes que se quieren dar.

Si esto va a ser verdad, ¿qué Constitución y qué leyes fundamentales y esenciales querrá darse al pueblo de Chile?

¡El momento actual es totalmente revolucionario, revolución serena y tranquila, como muchas veces la hemos soñado, como la entreviera Emilio Zola en "Trabajo"!

¿Quiénes van a dirigir esta revolución?

¿Quiénes lograrán dirigir las finalidades de la gran Asamblea Constituyente en perspectiva?

Si el proletariado divide sus finalidades y sus doctrinas en dogmatismos estrechos perderemos la oportunidad de ganar esta jornada, que ganada significaría un gran paso en el camino de la Revolución Social.

No habremos de hacernos la ilusión de que de esta Asamblea Constituyente vaya a surgir una República comunista ni anarquista, pero debemos trabajar para que surjan por lo menos los elementos con que hacerla un poco más adelante.

Por lo tanto el momento presente es el más culminante de nuestra historia.

Si la Asamblea Constituyente va a ser una libre asamblea, es el proletariado quien tendrá mayoría en esa Asamblea, y si el proletariado en mayoría no sabe guiarse, será la clase capitalista, en minoría en esa asamblea quien gana la partida.

Esta es, pues, nuestra advertencia.

Y nuestra voz de orden es: ¡Unirse y trabajar! Es decir trabajar creando y dando formas a las ideas que deben llevarse a la Asamblea Constituyente.

Una de las ideas fundamentales que deben cristalizarse en la Constituyente, es la desmoralización administrativa y legislativa. Por lo tanto la abolición del parlamentarismo debe ser un ideal unánime.

¿Sería necesario reemplazar el parlamentarismo por otra organización? ¿Cuál sería ella y en qué forma funcionaría?

Un sistema federal se impondría. Un sistema federal que entregue a los ciudadanos de las distintas regiones el derecho a trabajar por la grandeza de cada región [...]

Si no fuera sincera la Junta Militar, si factores extraños o surgidos del momento quisieran desviar la ejecución de las ideas del Manifiesto de la Junta Militar, sea el proletariado, obreros, empleados, etc., quienes se encarguen de llevarlo a la práctica.

A ejecutar el Manifiesto de la Junta Militar debe ser nuestra acción presente y futura, cueste lo que cueste.

El Manifiesto revela una nueva generación de idealistas entre los militares de Chile. Exijamos su realización lisa y llana. No pidamos por hoy la realización de nuestros ideales, exijamos la realización de esa parte de nuestros ideales, por poco que sea, o que nos parezca contenido en el Manifiesto de la Junta Militar.

¡A la labor y a la labor activa, todos! $!^{25}$.

El 14 de septiembre, el PCCh y la FOCH realizaron una gran manifestación en el Teatro O’Higgins de la capital. Recabarren reiteró lo expresado en los días anteriores, en especial, la desconfianza de los sectores populares ante las promesas de la Junta Militar y el papel jugado hasta entonces por los militares como represores del pueblo. Sin embargo,

\footnotetext{
${ }^{25}$ Luis E. Recabarren S., "Un juicio sobre el Manifiesto de la Junta Militar", Justicia, Santiago, 13 de septiembre de 1924.
} 
declaró que estos serían bienvenidos si reconocían haber sido el instrumento del poder, llamó a los comunistas y fochistas a mantenerse unidos para participar con afán en las nuevas bases que se daría a la República mediante la Asamblea Constituyente y formuló votos para que en lo posible se fundara la "República obrera del trabajo"26.

Durante el resto del año, comunistas y fochistas continuaron emplazando a los militares para que cumplieran sus promesas de reforma social y refundación política a través de la prometida Asamblea Constituyente. No obstante, a medida que transcurrían el tiempo y la Junta de Gobierno adoptaba un giro cada vez más conservador, alejándose de hecho de la línea anunciada a comienzos del movimiento militar de septiembre, la posición comunista-fochista -al igual que la de otros componentes del movimiento popular- se tornó más desconfiada y distante del gobierno. El 24 de septiembre, Salvador Barra Woll, uno de los principales dirigentes del PCCh y de la $\mathrm{FOCH}$, publicó un artículo asegurando que el movimiento militar fracasaría si en la nueva Constitución quedaban intactas las bases del orden social. Las esperanzas del proletariado en la Junta Militar, estimaba, seguían siendo válidas solo si la promesa de organizar una Asamblea Constituyente era respetada. Adelantando algunos elementos de lo que sería la política comunista en el anunciado proceso, este líder comunista-fochista señaló que en la Constituyente deberían estar presentes las fuerzas vitales de la nación, en primer lugar el proletariado obrero e intelectual. De no ser así, nada cambiaría para los sectores más desposeídos. La clase obrera debía, pues, intervenir en la generación de la nueva Constitución formando de inmediato el frente único para su salvación ${ }^{27}$.

En tanto, los cabecillas del PCCh y de la FOCH siguieron afinando su proposición de Asamblea Constituyente. El 22 de septiembre Justicia publicó un artículo en el que se planteó que en ella debían "estar representadas todas las clases sociales del país realizándose la elección fábrica por fábrica, taller por taller, repartición por repartición, sitio por sitio sin otro registro que las planillas de trabajo", "las verdaderas fuerzas del país", sin perjuicio de que, a su vez, tuvieran representación las "clases capitalistas e industriales". A la fórmula indicada días antes por el mismo órgano de prensa que preveía la elección de delegados a la Constituyente por fábricas o establecimientos industriales, mineros, salitreros y de otro tipo, se agregaron ahora representantes de los trabajadores de los fundos o haciendas, portuarios, del Ejército, la Marina, la Policía, de los profesores, universitarios, comerciantes, industriales, aparte de los ya señalados miembros de las direcciones centrales obreras y de todos los partidos políticos ${ }^{28}$.

Otro referente político significativo de los sectores populares, el Partido Democrático, también evolucionó desde una prudente expectativa inicial -mezclada con críticas a los militares por haber provocado la ruptura del orden constitucional- a un

\footnotetext{
26 "El movimiento militar y la clase trabajadora", Justicia, Santiago, 16 de septiembre de 1924. La reivindicación de la Asamblea Constituyente siguió apareciendo en la prensa comunista después del meeting del Teatro O’Higgins. Véase, entre otros, "Notas del día", Justicia, Santiago, 17 de septiembre de 1924; “Qué es una Asamblea Constituyente?”, Justicia, Santiago, 22 de septiembre de 1924.

${ }^{27}$ Salvador Barra Woll, "El movimiento militar irá al fracaso, si en la nueva Constitución de la República deja subsistente las bases actuales de la Sociedad. Nuestro pensamiento en las circunstancias actuales", El Despertar de los Trabajadores, Iquique, 24 de septiembre de 1924. Reproducido más tarde en Justicia, Santiago, 7 de octubre en 1924.

28 “QQué es una Asamblea Constituyente?”, Justicia, Santiago, 22 de septiembre de 1924.
} 
posicionamiento francamente opositor. A mediados de octubre, el joven Fernando García Oldini presentó un proyecto de voto en el Directorio General de este partido criticando de manera muy dura al gobierno por no haber hecho nada a fin de cumplir su promesa de convocatoria a una Asamblea Constituyente, ni dictado leyes en beneficio de las clases trabajadoras, adoptando en cambio medidas que violaban las garantías constitucionales, como el establecimiento de tribunales militares y otras que atropellaban las libertades individuales $^{29}$. En las semanas posteriores, distintos organismos y dirigentes de "la Democracia" añadieron nuevas quejas y críticas respecto de la acción de los gobernantes militares, sobre todo respecto de la conculcación de libertades, persecuciones políticas y medidas lesivas de los intereses de los trabajadores, pero con menor énfasis que los comunistas $\mathrm{y}$ fochistas en el incumplimiento de la convocatoria a una Asamblea Constituyente $^{30}$.

Al igual que los demócratas, otras colectividades que habían conformado la Alianza Liberal empezaban a pronunciarse sin tapujos contra la dictadura militar debido a su creciente orientación conservadora. Por ejemplo, en la Convención del Partido Radical celebrada el 2 de noviembre de 1924, numerosos delegados formularon fuertes críticas a la Junta de Gobierno, acusada de incumplimiento de su programa, y exigieron la convocatoria a una Asamblea Constituyente ${ }^{31}$.

A fines de 1924 solo los sectores más conservadores mantenían su apoyo a la Junta Militar. En el movimiento obrero, en las fuerzas de izquierda y en las franjas más progresistas del liberalismo en cambio, crecía la demanda por la restauración del régimen constitucional para avanzar a una nueva institucionalidad política vía Asamblea Constituyente. Una fracción de los militares, la oficialidad joven que había sido el alma y el motor del movimiento de septiembre, fue la encargada de poner una vez más la cuestión constitucional en la agenda política nacional mediante el golpe de Estado del 23 de enero de 1925 que desplazó a las más altas jerarquías militares del gobierno de la República. Su llamado al autoexiliado Alessandri Palma para que volviera al país a terminar su mandato presidencial junto a su declaración a favor de la convocatoria a una Asamblea Constituyente generaron nuevas esperanzas y un clima de febril actividad de las dirigencias del movimiento popular.

El domingo 25 de enero, apenas un par de días después de consumado el nuevo putsh e instalado el gobierno provisorio cívico-militar, por iniciativa de la Junta Ejecutiva Federal de la FOCH se reunieron en su local de la calle Río de Janeiro en Santiago enviados de numerosas organizaciones de obreros, empleados y estudiantes, a fin de discutir la actitud que debía asumir la clase asalariada en el nuevo escenario político creado por el golpe del 23 de enero. Entre los asistentes a esta reunión amplia se contaron delegados de las siguientes entidades: Comité Ejecutivo y la Junta Provincial de Santiago del PCCh, Unión General de Obreros Metalúrgicos, Federación Obrera de Magallanes (FOM), Asociación General de Profesores, Unión en Resistencia de Obreros Metalúrgicos

\footnotetext{
29 "Porque se ataca en el Directorio Demócrata al actual Gobierno", El Diario Ilustrado, Santiago, 19 de octubre de 1924.

${ }^{30}$ Sergio Grez Toso, El Partido Democrático de Chile. Auge y ocaso de una organización política popular (1887-1927), Santiago, Lom Ediciones, 2016, págs. 356-358.

31 "La Convención Extraordinaria del Partido Radical", La Libertad, Santiago, 9 de noviembre de 1924.
} 
de la Fundición Libertad, Federación de Empapeladores, Comité General de Obreros Ferroviarios, Federación de Estudiantes de Chile $(\mathrm{FECH})^{32}$, Unión General de Empapeladores en Resistencia, Unión de Hojalateros y Gásfiters, Unión de Empleados de Chile, Centro Cultural "El Despertar", Comité Pro Libertades Públicas, Comité Frente Único Civil, Federación de Obreros de Imprenta de Chile (FOI), Federación de Obreros y Obreras del Calzado, además de la dirección fochista. La reunión fue presidida por el secretario general de la Junta Federal de la FOCH, el comunista Luis Víctor Cruz y actuó como secretario Pedro González, militante del mismo partido ${ }^{33}$.

Poniendo en evidencia la estrecha simbiosis existente entre la central sindical y el PCCh, asimismo del control total que este último ejercía sobre la primera, Cruz manifestó a la asamblea que los máximos organismos dirigentes de ambas colectividades acababan de adoptar "una resolución trascendental relacionada con la revolución de la juventud militar" cuya idea central apuntaba al interés que la clase obrera tenía en acelerar las transformaciones prometidas por los militares en sus manifiestos de septiembre y de enero, imprimiendo para ello un clima de agitación que condujera a las masas a tener una participación importante en los acontecimientos que se estaban desarrollando ${ }^{34}$. Luego de la intervención de más de una docena de personas - muchos de ellos destacados activistas comunistas- quienes manifestaron su acuerdo con la iniciativa de la FOCH, su adhesión a la Junta Revolucionaria para que esta cumpliera sus promesas y su coincidencia en la necesidad de la unión de las fuerzas proletarias a fin de exigir el "cumplimiento fiel y leal del programa del once de septiembre y del manifiesto último de la guarnición de Santiago", se acordó fundar un Comité Nacional Obrero que llevara a la práctica estos propósitos. El flamante organismo quedó compuesto por el comunista Manuel Hidalgo en representación de la FOCH, su camarada Salvador Barra Woll por el PCCh, Humberto Gatica por las organizaciones autónomas, Pedro Moyano por los ferroviarios, Gregorio Guerra por los empleados, y el profesor y abogado radical Carlos Vicuña Fuentes por los intelectuales. Se convino invitar a la anarcosindicalista Industrial Workers of the World (IWW) para que designara un delegado ante el comité ${ }^{35}$.

No era la primera vez que algunas de estas entidades intentaban conformar una coordinación, pero hasta entonces sus esfuerzos no habían prosperado. La nueva situación ofrecía, sin embargo, mejores posibilidades para una confluencia más fructífera. Así lo entendieron sus protagonistas. Desde el primer momento, el recién creado Comité Nacional Obrero desplegó una intensa actividad, un día después de su instauración, el 26 de enero, emitió una declaración señalando que le era "imposible resistir la presión de todo el proletariado del país" que amenazaba con un paro general inmediato si el Gobierno Militar retrocedía ante el cumplimiento de sus promesas y aceptaba "la indigna transacción propuesta por la oligarquía”, consistente en impedir el regreso del presidente Alessandri. La

\footnotetext{
32 Sobre la Federación de Estudiantes, véase Fabio Moraga Valle, "Muchachos casi silvestres". La Federación de Estudiantes y el movimiento estudiantil chileno 1906-1936, Santiago, Ediciones de la Universidad de Chile, 2007.

33 “La formación del Comité Obrero Nacional”, Justicia, Santiago, 27 de enero de 1925.

${ }^{34}$ Ibid. Véase el manifiesto conjunto de la FOCH y el PCCh en "La Junta Ejecutiva Federal de la Federación Obrera de Chile y el Partido Comunista han dado a conocer el siguiente manifiesto dirigido a los obreros", El Mercurio, Santiago, 25 de enero de 1925.

${ }^{35}$ Ibid.; "Ayer se efectúa una asamblea de delegaciones obreras", El Mercurio, Santiago, 26 de enero de 1925.
} 
lucha presente -estimaba el Comité- era de la casi totalidad del país, contra una reducida oligarquía que no encarnaba "ni las ideas, ni los sentimientos, ni los anhelos, ni los intereses de la Nación". Respondiendo a la gran "exaltación del pueblo" y a la necesidad inmediata de actuar con inteligencia y energía, el Comité declaró que esa misma tarde decretaría un paro general en todo el país a fin de expresar su adhesión incondicional y decidida al Ejército y exigir el cumplimiento del manifiesto de la guarnición de la capital ${ }^{36}$.

Esa tarde el comité directivo entregó al comandante Marmaduke Grove en el palacio de La Moneda dicha declaración. El portavoz de los militares jóvenes, pese a agradecer el gesto de los delegados populares, les hizo saber que el paro general podría perturbar la marcha del país, por lo cual les rogó se abstuvieran de realizarlo, agregando que las promesas formuladas en el manifiesto del 23 de enero serían cumplidas ${ }^{37}$. El paro quedó en puntos suspensivos y el Comité Obrero se abocó a otras tareas. El comandante Grove envió un telegrama a Alessandri, quien se encontraba en Roma, para informarle acerca de su plena adhesión a la nueva administración y solicitarle su regreso al país en términos afectuosos aunque perentorios:

[...] ruega a su querido Presidente vuelva inmediatamente a reasumir su cargo único medio de mantener la paz pública y salvar a la Patria. El momento es de una gravedad trascendental y decisiva, único en la historia de Chile. Usted no puede abandonar el ideal democrático ${ }^{38}$.

El mismo 26 de enero se formó un subcomité encargado del trabajo en la capital, se realizó un meeting seguido de un desfile en el centro de la ciudad para emplazar a los militares a cumplir con sus promesas y los dirigentes del Comité Nacional Obrero dieron cuenta de sus actividades ante una concurrida asamblea del gremio de ferroviarios. En la manifestación callejera se destacaron como oradores los anarquistas Armando Triviño por la IWW, Humberto Martones y Alberto Baloffet, el comunista Salvador Barra Woll y el radical Carlos Vicuña Fuentes, quienes coincidieron en señalar que se necesitaba "toda la actividad y entusiasmo de los trabajadores para luchar por obtener el cumplimiento de las aspiraciones que alentaban los diversos organismos obreros" 39 . Mientras ocurría todo esto,

\footnotetext{
36 "Las manifestaciones públicas y la actuación de los obreros”, El Mercurio, Santiago, 27 de enero de 1925. Esta declaración fue firmada por Carlos Vicuña Fuentes, Manuel Hidalgo, Pedro León Loyola L., Carlos Alberto Martínez y Pedro Moyano. Loyola y Martínez figuran por primera vez conformando el Comité Obrero. Al parecer su incorporación sería posterior a la formación del organismo, tal vez en representación de nuevas entidades asociadas a él. Cabe destacar que Carlos Alberto Martínez había sido secretario general de la FOCH durante las grandes movilizaciones de la Asamblea Obrera de Alimentación Nacional (AOAN) en 1918 y 1919, además de destacado líder del Partido Obrero Socialista (POS); fue uno de los escasos dirigentes de este partido que se desvinculó de la organización cuando esta se transformó en PCCh a comienzos de 1922. No obstante su disidencia, se mantuvo cercano a Recabarren y continuó actuando como dirigente mutualista, sin militancia partidaria; en 1933 fue uno de los fundadores del Partido Socialista de Chile. Pedro León Loyola Leyton era un joven universitario que en 1918 había presidido la Federación de Estudiantes de la Universidad de Chile (FECH); posteriormente destacaría como filósofo autodidacta y efímero rector de la Universidad de Chile a la caída de la dictadura de Ibáñez (1931).

37 "Las manifestaciones públicas y la actuación de los obreros", op. cit.

${ }^{38}$ Ibid.

39 "Actividades de los organismos obreros durante el día de ayer", El Mercurio, Santiago, 27 de enero de 1925.
} 
una delegación del Comité que había sido enviada a las provincias del sur regresó a Santiago y acudió a entrevistarse con representantes de la Junta de Gobierno en el palacio presidencial $^{40}$. Ese día, el Comité Nacional Obrero acordó sesionar en forma permanente para promover la realización de un paro nacional cuando la situación lo demandara; estudiar las bases sobre las cuales se haría la nueva Constitución de la República; realizar una Convención Obrera nacional y continuar manifestando por medio de meetings, reuniones y comicios públicos, la necesidad del regreso del presidente Alessandri para normalizar la situación ${ }^{41}$. La idea del paro general para defender los intereses de los trabajadores, impedir una componenda entre las elites y apoyar las reformas prometidas por los militares continuaba rondando en las organizaciones sociales, sobre todo laborales. Antes de tomar una decisión en ese sentido, la Junta Ejecutiva de la FOCH consultó la opinión de sus bases en distintas provincias. Casi por unanimidad, desde Tarapacá, Antofagasta, Talcahuano, Concepción, Valdivia, Valparaíso, Santiago y otros lugares, los trabajadores del salitre, del carbón, los ferroviarios, los portuarios y marítimos, y otros gremios respondían de manera afirmativa a la propuesta del paro nacional, situación que llevó a la FOCH a decidir que dicha movilización se llevaría a cabo si la Junta de Gobierno no liberaba a los presos "por cuestiones sociales" 42 .

El paro no llegó a concretarse porque al día siguiente, 27 de enero, la Junta de Gobierno y el Comité Militar Revolucionario acordaron la constitución de un Gobierno Provisional a la espera de que Alessandri retornara para reasumir sus funciones como presidente de la República, asimismo anunciaron varias medidas, algunas de las cuales satisfacían en parte ciertas demandas de los trabajadores como la promesa de convocatoria a "una Asamblea Constituyente de origen popular a fin de plasmar el programa de reformas ofrecido al país en el manifiesto del 11 de Setiembre de 1924" y la libertad incondicional de los detenidos por los sucesos del 23 de enero, asegurando "la inmunidad futura de todos los sindicatos de haber participado en dichos sucesos"43. Esa tarde, Carlos Vicuña Fuentes, Salvador Barra Woll, Manuel Hidalgo, el dirigente de los ferroviarios Ángel Mella y Humberto Gatica concurrieron a La Moneda a informar a la Junta de Gobierno de los acuerdos tomados por el Comité Nacional Obrero en su sesión de la mañana, siendo el primero de estos compromisos el rechazo de la organización de una Asamblea Constituyente antes del retorno del presidente constitucional, porque esta debía realizarse en pleno régimen civil, en un clima de tranquilidad y normalidad que el país aún no había alcanzado. Los comisionados populares pidieron, además la inmediata libertad incondicional a los presos y procesados por delitos políticos y electorales, esto es, a los encausados a raíz de los hechos que culminaron en la matanza de obreros de la oficina salitrera de San Gregorio (1921), a los condenados por los sucesos de Puerto Natales

\footnotetext{
${ }^{40}$ Ibid. Los integrantes de esta comitiva eran Luis Dávila, Luis Ayala (dirigente de los tranviarios), Epifanio Campaña, Juan Pradenas Muñoz (demócrata), Gaspar Mora Sotomayor (demócrata), Óscar Schnacke (anarquista), Roberto Meza Fuentes (expresidente de la FECH), Juan Zamorano Labbé, Leonidas Bravo y Eugenio González Rojas (anarquista).

41 "Actividades de los organismos obreros durante el día de ayer", op. cit.

${ }^{42}$ Ibid.

43 Archivo Nacional de la Administración, Colección Fondos Ministeriales, Ministerio del Interior, Oficios, vol. 6373 (1925), César León, Oficio al Señor Presidente de la Excma. Corte Suprema, Santiago, 28 de enero de 1925, s.fj.
} 
(1919), a los involucrados en el llamado "proceso de los subversivos" (1920) aún en curso en Valparaíso, a los comprendidos en los sumarios iniciados con motivo de los acontecimientos electorales del 2 de marzo de 1924 y en general a todos los ciudadanos perseguidos por ideas, opiniones, asociaciones públicas o actividades de carácter social o político. Los delegados del Comité Nacional Obrero exigieron igualmente la constitución de un gabinete civil adepto sin ambages al presidente constitucional o, en su defecto, uno militar que asumiera en forma provisoria y disipara del ánimo del pueblo "el justo temor" de que la reacción penetrara mediante intrigas a través de un ministerio de transacción. Emilio Bello Codesido, presidente civil de la Junta de Gobierno, respondió indicando que dedicaría atención preferencial a las peticiones de los trabajadores, que ya había solicitado los antecedentes de los procesados por cuestiones sociales y políticas a fin de darle solución de la manera más justa y pronta posible ${ }^{44}$.

Satisfecho de sus logros en tan breve plazo, el flamante estado mayor de obreros, empleados, profesores, estudiantes y jóvenes intelectuales emitió un nuevo manifiesto para anunciar la primera victoria y fijar las tareas inmediatas:

Antes de 48 horas las clases populares han obtenido su primera aspiración: el retorno inmediato e incondicional del Presidente Alessandri. Necesita ahora, no dormirse sobre los laureles, sino imponer una libre Asamblea Constituyente, de la cual surja un estatuto fundamental de la nación que no sea obstáculo a la implantación de los futuros ideales del pueblo trabajador.

El Presidente Alessandri debe regresar al país en brazos del pueblo, a gobernar con el pueblo y para el pueblo.

El esfuerzo popular que ha sacudido vigorosamente a la nación obtiene con ello, su triunfo inicial. La oligarquía abandona sus baluartes coloniales y retrocede con sus banderas en derrota. Hay que terminar con ella. El porvenir de Chile exige su muerte total y definitiva.

No obstante, ahora más que nunca, el pueblo debe erguirse con el espíritu vigilante y con una férrea voluntad dispuesta a la acción constructiva. A la exigencia del regreso del Presidente Alessandri, debe suceder la exigencia de las más indispensables reformas económicas y sociales. Es preciso renovar el país, y esta renovación debe hacerla también el pueblo trabajador, ${ }^{45}$.

El Comité Nacional Obrero anunció entonces la segunda etapa de su labor: conseguir la representación de todas las fuerzas laborales del país en la Gran Asamblea Constituyente que debería convocarse en fecha próxima. El panorama parecía auspicioso, el momento era definido por este organismo como una "hora casi definitiva en la historia nacional", había "llegado la hora de no transigir", "la hora de implantar los principios más elementales de solidaridad y justicia social" ${ }^{\text {46 }}$.

\footnotetext{
44 "El Comité Nacional Obrero y la formación de la Asamblea Constituyente", El Mercurio, Santiago, 29 de enero de 1925. Véase también Actividades del Comité Obrero Nacional, Justicia, Santiago, 29 de enero de 1925.

45 Ibid.

${ }^{46}$ Ibid.
} 


\section{La política constituyente comunista}

El golpe militar del 23 de enero fue leído por la dirección del PCCh como una oportunidad que el proletariado y el partido debían aprovechar para defender de manera independiente sus intereses fundamentales. En términos comparativos, la línea diseñada podría definirse como de mayor cercanía con la "juventud militar" que la levantada frente al movimiento de septiembre y la anterior Junta Militar de Gobierno. Desde la perspectiva del liderazgo comunista, se trataba de un acercamiento táctico en función de la lucha contra el enemigo común representado por la "oligarquía conservadora". Como primer paso destinado a implementar esta política, el 24 de enero, una comisión compuesta por el secretario general de la Junta Ejecutiva Federal de la FOCH, Luis Víctor Cruz y Manuel Hidalgo, miembro de la misma; Carlos Sepúlveda, secretario del Comité Ejecutivo Nacional del PCCh y Salvador Barra Woll, director de Justicia, se entrevistó con los integrantes de la Junta de Gobierno y el teniente coronel Carlos Ibáñez del Campo, uno de los principales promotores del movimiento, para expresar las razones de su apoyo al nuevo poder. Era la primera vez -explicaba Justicia- que estas instituciones obreras ofrecían su adhesión a un gobierno que no era el de su clase, esto debido a "una circunstancia histórica propia de la lucha de clases" consistente en la lucha entre la oligarquía y la democracia por la toma del poder. Los trabajadores -explicó este órgano de prensa- daban su apoyo, solo para oponerse al resurgimiento de la reacción ${ }^{47}$.

Un manifiesto conjunto del PCCh y de la FOCH proclamó la convergencia de propósitos de la clase obrera y los oficiales reformistas: "La juventud militar se ha adelantado a lo que nosotros pocos momentos más tarde debíamos iniciar". Por ello llamó a los trabajadores a concurrir "con entusiasmo a empuñar las armas a los cuarteles", para defender con sus vidas "la bandera de la regeneración republicana enarbolada por la juventud militar" y para cooperar en la preservación de los principios del movimiento en curso. Sacando enseñanzas de tantas decepciones y experiencias nefastas desde la guerra civil de 1891, era preciso -sostenían los firmantes de este documento- evitar la repetición de tales hechos asegurando la presencia "en proporción equitativa" de la clase proletaria en el gobierno $^{48}$.

Barra Woll dio más consistencia teórica y alcance preciso a estas posiciones mediante una serie de artículos publicados en el órgano fochista-comunista. Con estilo claro y directo definió como motivo primordial de la adhesión de la clase trabajadora a la juventud del Ejército, su propósito de convocar a una Asamblea Constituyente, expresando

\footnotetext{
47 "El Partido Comunista y la Federación Obrera de Chile, adhieren moral y materialmente al nuevo movimiento militar", Justicia, Santiago, 25 de enero de 1925. Sobre la política comunista frente al golpe del 23 de enero de 1925 y las instituciones militares a partir de la nueva coyuntura, véase José Díaz, Militares y socialistas en los años veinte. Orígenes de una relación compleja, Santiago, Universidad ARCIS, 2002, págs. 150-169.

48 Junta Ejecutiva Federal de la Federación Obrera de Chile y Comité Ejecutivo Nacional del Partido Comunista de Chile, "A la clase trabajadora del país todo nuestro apoyo", Justicia, Santiago, 25 de febrero de 1925. Firman por la FOCH: Luis V. Cruz S., secretario general, Elías Lafertte G., Manuel Hidalgo y Pedro J. González. Por el PCCh: Carlos Sepúlveda, secretario general, Galvarino Gil, Salvador Barra Woll, Tomás Conelli, Luis A. Guzmán y Lino Paniagua. Conviene recalcar que todos los dirigentes fochistas eran, al mismo tiempo, conocidos líderes comunistas.
} 
el deseo que el gobierno de facto garantizara la libre acción de la clase obrera para estar representada en el futuro Parlamento y desarrollar sus actividades societarias y políticas sin frenos de abusos de poder o de la clase capitalista. El régimen militar tenía que durar hasta que la elección de nuevos poderes restableciera la normalidad civil, regresando enseguida el Ejército a sus cuarteles puesto que su manejo del Estado podía ser admitido solo en casos excepcionales como el que se estaba viviendo y para objetivos como los declarados en su manifiesto. Nadie debía equivocarse, sostenía Barra Woll, esta actitud del proletariado revolucionario -la definida por su partido, el Comunista- era una conducta determinada por "un incidente de la lucha de clases, por las circunstancias históricas". No se trataba, pues, de una adhesión incondicional al nuevo gobierno sino de una coincidencia táctica, circunstancial ya que los objetivos estratégicos de los comunistas se mantenían inalterables:

Nuestra finalidad es la toma del poder por el proletariado para el establecimiento de su dictadura de clase, y la lucha de hoy, no es otra cosa que un incidente que tiende a asegurar este objetivo futuro por medio de nuestro contacto con las tropas.

No aspiramos a una colaboración en el gobierno que sería una traición que repudiamos con toda la fuerza de nuestras convicciones. Más todavía, estamos plenamente convencidos que las fuerzas liberales que hoy están en el poder frustrarán seguramente todas las expectativas del proletariado y solo habremos conseguido una relativa y transitoria garantía para nuestro desarrollo la que pronto desaparecerá con la normalización del régimen burgués. Habremos conseguido probar a la clase obrera que la solución de su problema está en su propia dictadura y nunca en cualquiera de las ramas en que se divide la burguesía ${ }^{49}$.

Con el apoyo de los trabajadores a la Junta Militar desaparecería el peligro de la reacción oligarco-conservadora; sin embargo, de su muerte nacería el peligro de la reacción liberal-burguesa, algo más tolerante, no obstante siempre enemiga de las conquistas económico-sociales de la clase proletaria. ¿Por qué entonces apoyar dicho movimiento liberal?, se preguntaba retóricamente Barra Woll. Y respondía: "Porque la masa obrera, una gran parte de los empleados especialmente, aún no pierden la fe en la burguesía liberal a la que ni siquiera saben distinguir bien como clase explotadora" ${ }^{\text {"50 }}$. Se trataba, pues, de hacer obra pedagógica en las masas, ayudarles a entender que su emancipación se conquistaría cuando se hubieran desprendido de ella, cuando hubieran comprendido que era su enemiga. Había probabilidades de que la promesa de la Constituyente se cumpliera, aunque en el momento de convocarla se vería que sus bases no consultarían la representación obrera sindical revolucionaria porque lo impediría en resguardo de sus intereses de clase. "Queremos una Constituyente; pero a base gremial", concluía Barra Woll. Si no era de ese modo, la burguesía habría traicionado una vez más al proletariado, sirviéndose de él para sus propios fines ${ }^{51}$.

\footnotetext{
49 Salvador Barra Woll, "Nuestras aspiraciones. Nadie equivoque nuestra actitud", Justicia, Santiago, 27 de enero de 1925.

${ }^{50}$ Salvador Barra Woll, "Nuestros puntos de vista. La Constituyente y sus bases", Justicia, Santiago, 29 de enero de 1925. Este artículo también fue publicado en El Comunista, Antofagasta, 24 de febrero de 1925. ${ }^{51}$ Ibid.
} 
Desde la perspectiva comunista expresada por el director de Justicia, la participación del proletariado en el proceso constituyente que se estaba iniciando en Chile solo se justificaba a condición de hacerlo en función de su emancipación, no para contribuir a crear nuevos eslabones que lo ataran al carro de la explotación y de la tiranía capitalista. El proletariado debía luchar para que la Constituyente estuviese compuesta en un $90 \%$ por "obreros del músculo y del pensamiento" y para que sus resultados fueran la libertad para los obreros, la abolición de la propiedad privada y su sustitución por la propiedad social de la tierra, del trabajo y de sus frutos ${ }^{52}$. Reafirmando de manera clara y simple la posición comunista en la coyuntura abierta por el golpe del 23 de enero, Barra Woll afirmó que lo que el PCCh sostenía y trataba de imponer era la Constituyente de base funcional y una Constitución conforme al más avanzado principio que permitieran las circunstancias y la presión del proletariado, sintetizando en un par de frases la línea de su partido para dicho período: "En una palabra apoyamos y luchamos por el cumplimiento del Manifiesto del 11 de Septiembre y no por el regreso del señor Alessandri. Ese número del programa no es del Partido Comunista"53. La "Constituyente Chica" serviría para señalar con precisión y claridad meridiana "el verdadero secreto de la liberación de las masas obreras oprimidas, explotadas e ignaras", conformándose como una expresión del poder obrero, al igual que en la Constituyente grande, en las agitaciones de las masas trabajadoras, en todas las acciones aún a sabiendas que la conquista de ese poder no podría realizarse más que por la revolución social ${ }^{54}$.

Si bien los comunistas no reivindicaban el retorno de "el León", estaban llanos a flexibilizar su posición si esto contribuía al derrocamiento de la reacción oligárquica. Frente a dicho peligro estaban dispuestos a implementar una defensa común, mas no asimilarse a los liberales. "No queremos tampoco que se nos confunda con los radicales, liberales u otros elementos burgueses que luchan por los fines inmediatos del momento", explicaba a mediados de febrero El Comunista de Antofagasta, agregando que si el movimiento antioligárquico triunfaba, los liberales quedarían satisfechos: "Nosotros no. Tenemos mucho que cambiar todavía. Del liberalismo burgués, al comunismo hay un mundo de distancia" $" 55$.

Los comunistas no se hacían ilusiones desmedidas acerca de los resultados que podría arrojar una Asamblea Constituyente -estaban conscientes que de ella no saldría una panacea que curara los males que aquejaban a la clase más desvalida ${ }^{56}$ - no obstante entendían que su participación y la de los trabajadores en este proceso era una mediación táctica importante en la acumulación de fuerzas que permitiría un escenario más favorable para las luchas del futuro. "Si hoy apelamos a la Constitución del Estado, para reunirnos libremente sin previo aviso y gozamos de la relativa libertad de palabra y prensa para la divulgación de las ideas renovadoras - razonaba el comunista Manuel Leiva, presidente

\footnotetext{
${ }^{52}$ Ibid.

${ }^{53}$ Salvador Barra Woll, "Comité Obrero Nacional. Firmas apócrifas", Justicia, Santiago, 15 de febrero de 1925. Reproducido también en "Comité obrero nacional", La Jornada Comunista, Valdivia, 19 de febrero de 1925.

${ }^{54}$ Salvador Barra Woll, "La Constituyente de obreros e intelectuales", Justicia, Santiago, 6 de marzo de 1925.

55 "La conspiración de la oligarquía santiaguina", El Comunista, Antofagasta, 13 de febrero de 1925.

56 "La nueva Constituyente. Un paso más que hay que aprovechar", El Comunista, Antofagasta, 3 de marzo de 1925.
} 
provisorio del Comité Nacional Obrero Frente Único de Obreros y Empleados Pro Reformas Constitucionales de Viña del Mar- ¿cuánto mayor provecho no sacaríamos si de la Asamblea Constituyente pudiéramos hacer prevalecer nuestro pensamiento en el sentido indicado?", añadiendo que no debía confundirse la intención que los guiaba al involucrarse en esta campaña:

No crean los camaradas que de esa asamblea, saldrá la total felicidad para la clase trabajadora, no, no te [sic] lo figuréis camaradas, pero tampoco desconozcáis que de esa asamblea también puede surgir un mejor horizonte que haga menos dificultoso el andar de las ideas que han de traer la emancipación integral de la clase trabajadora. También puede ocurrir el caso que abandonando toda iniciativa la clase trabajadora en este sentido, entregara a la clase capitalista el árbitro de formar la burguesía a su sabor la nueva Constitución ${ }^{57}$.

El plan de una Asamblea Constituyente de base gremial, con porcentajes predeterminados de representación de los distintos sectores sociales, para de esta forma asegurar la hegemonía de los trabajadores manuales e intelectuales y de sus aliados, fue desde entonces el elemento central de la política comunista en el incipiente proceso constituyente. La propuesta formulada por primera vez en septiembre del año anterior fue actualizada y presentada ante el Comité Nacional Obrero a fines de enero.

El ambiente era propicio en el seno del frente amplio popular para un proyecto de este tipo. Al desprestigio del sistema parlamentarista y de sus partidos se agregaban las ideas corporativistas, muy en boga por aquel tiempo en Europa, que eran retomadas en Chile por distintos sectores que buscaban nuevas alternativas de representación política depuradas de las distorsiones y prácticas corruptas que imperaban en la política nacional. Por eso no fue difícil que la proposición comunista y fochista fuera rápidamente aceptada por sus aliados del Comité Nacional Obrero, del mismo modo como lo fue su proyecto de emprender un ejercicio de deliberación previo a la Asamblea Nacional Constituyente que las nuevas autoridades del país habían prometido convocar.

\section{La preparación de la Asamblea Constituyente de Asalariados e Intelectuales}

El 30 de enero, el Comité Nacional Obrero acordó realizar una reunión o Congreso de asalariados e intelectuales, al que concurrieran junto a los proletarios, los empleados, educadores, estudiantes, académicos y profesionales, a fin de discutir un proyecto de Constitución Política que reflejara las aspiraciones inmediatas del proletariado y de quienes simpatizaran con "los modernos principios de justicia y solidaridad". Luego de logrado ese acuerdo, se desarrollaría una gran campaña nacional a fin de elegir la mayor cantidad posible de delegados que defendieran los intereses de los sectores populares en la Asamblea Constituyente que convocaría Alessandri. En principio, en la Constituyente de Asalariados e Intelectuales (o "Constituyente Chica" como se comenzó a llamar informalmente) participarían mil personas, de acuerdo a estos porcentajes: proletarios, 45\%; empleados, $20 \%$; profesores, $20 \%$; estudiantes, $7 \%$ y profesionales e intelectuales, $8 \%$. Los trabajos

57 "Viña del Mar", Justicia, Santiago, 5 de febrero de 1925. 
preparatorios del Congreso que se efectuaría el 21 de febrero estarían a cargo de una comisión nombrada por el Comité Nacional Obrero. Las inscripciones de congresales quedarían a cargo de un subsecretario para cada uno de los cinco grupos. El subsecretario de los proletarios sería designado por una asamblea mixta citada por el Comité Nacional Obrero, en la que se fijaría el porcentaje de participación de las fuerzas de cada organización obrera del país; el de los empleados sería nombrado por la Unión de Empleados de Chile; el de los maestros por la Asociación General de Profesores de Chile; el de los estudiantes por la Federación de Estudiantes de Chile y el encargado de inscribir a los intelectuales sería designado por el Comité Nacional Obrero ${ }^{58}$.

Aunque en la reunión en que fueron adoptados estos primeros acuerdos no estuvieron presentes la Asociación General de Profesores de Chile, ni la Unión de Empleados, ni la Federación de Estudiantes de Chile -sino esencialmente los obreros a través de la FOCH y las entidades con mayor influencia comunista- en los días posteriores se fueron incorporando los referentes convocados que no habían llegado a la primera cita ${ }^{59}$. El Comité Nacional Obrero y la convocatoria a la "Constituyente Chica" fueron ganando amplitud. A comienzos de febrero, se realizó una reestructuración de este quedando Manuel Hidalgo como presidente, Salvador Barra Woll en el cargo de secretario y Carlos Vicuña Fuentes como tesorero general ${ }^{60}$. Luego se designó una comisión de propaganda compuesta por Juan Pradenas Muñoz (exdiputado y líder demócrata), Pedro León Ugalde (exdiputado radical), Alberto Baloffet (anarquista), Fernando García Oldini (demócrata), Luis Ayala (dirigente del Consejo de Tranviarios de Santiago) ${ }^{61}$, Carlos Sepúlveda (secretario del Comité Ejecutivo Nacional del PCCh), Epifanio Campaña y Rigoberto Pérez. A su vez, la asamblea general integró el Comité Ejecutivo con el expresidente de la FECH Roberto Meza Fuentes, Ramón Jerez y Luis Ayala, y nombró, además, el subcomité de Santiago. Este último quedó conformado por Ambrosio Torres, delegado de los ferroviarios; Manuel Olave, en representación de la Federación Santiago Watt; Lino Paniagua por el PCCh; Julio Moya por la FOCH; el ácrata Alberto Baloffet por la Universidad Popular Lastarria; Luis Aparicio por los empleados; Roberto Meza Fuentes por los estudiantes; Miguel Ruz por la Asociación General de Profesores; Óscar Salas por la IWW; Víctor Troncoso por los docentes; Pedro León Ugalde por el Partido Radical y Juan Pradenas Muñoz por el Partido Democrático. Las nuevas incorporaciones reflejaban la pluralidad de fuerzas políticas e ideológicas que estaba adquiriendo el Comité Nacional Obrero, preludio de las discusiones

\footnotetext{
58 "Un congreso constituyente que será formado por asalariados e intelectuales", El Mercurio, Santiago, 31 de enero de 1925; "Las bases del próximo Congreso Constituyente de asalariados e Intelectuales", Justicia, Santiago, 1 de febrero de 1925; "La organización de un congreso constituyente de obreros e intelectuales". El Sur, Concepción, 31 de enero de 1925; "Los asalariados e intelectuales preparan un congreso constituyente", El Mercurio, Valparaíso, 1 de febrero de 1925.

59 "Preparando el Congreso Constituyente de asalariados", El Mercurio, Santiago, 1 de febrero de 1925.

60 “Actividades del Comité Nacional Obrero", El Mercurio, Santiago, 3 de febrero de 1925.

61 Luis Ayala Poblete fue secretario general del gremio de tranviarios de Santiago y presidente de la Convención Gremial del Rodado en 1924. En octubre de 1925 sería uno de los fundadores de la Unión Social Republicana de los Asalariados de Chile (USRACH). En 1927 fue deportado por Ibáñez. Más adelante militó en el PCCh. Armando de Ramón, Biografías de Chilenos. Miembros de los poderes Ejecutivo, Legislativo y Judicial 1876-1973, vol. I, Santiago, Ediciones Universidad Católica de Chile, 1999, pág. 118; Biblioteca del Congreso Nacional, Historia Política Legislativa del Congreso Nacional de Chile, http://historiapolitica.bcn.cl/resenas_parlamentarias/wiki/Luis_Ayala_Poblete
} 
y enfrentamientos que se desarrollarían más tarde en el proyectado Congreso Constituyente de Asalariados e Intelectuales ${ }^{62}$.

La incorporación de nuevos referentes políticos suscitó un primer conflicto interno pues el portavoz del PCCh, Salvador Barra Woll, protestó por el nombramiento de emisarios de partidos burgueses, sosteniendo que este movimiento era "netamente obrero y con fines revolucionarios". El Comité -aseveró- era un Frente Único Obrero y no obreroburgués. La protesta fue desechada por tres votos contra dos y uno en blanco, aceptándose todos los nombres propuestos. Acto seguido, el PCCh sufrió una segunda derrota en el seno del organismo de convergencia al negársele su participación en tanto partido porque afirmaron los delegados de mayoría- este ya estaba incluido a través de los comunistas que pertenecían a los sindicatos fochistas. Barra Woll alegó que siendo la "Constituyente Chica" un acto político, correspondía dar un espacio al partido por cuanto las organizaciones sindicales se identificaban en la acción del PCCh, lo que hacía imprescindible que este tomara parte oficialmente en el evento para defender el punto de vista revolucionario que los elementos burgueses tratarían de desvirtuar. Esa misma noche, luego de escuchar la cuenta de Barra Woll, el Comité Ejecutivo Nacional del PCCh decidió retirar su enviado ante el Comité, pidiendo a la vez la salida de todos los elementos políticos burgueses ${ }^{63}$.

El razonamiento de la dirección comunista expresado en una nota enviada al presidente del Comité Nacional Obrero, unía a la denuncia de voceros de "partidos burgueses" como elementos cuyas doctrinas y finalidades eran contrarias a los intereses del proletariado, su rechazo al criterio de la mayoría de sus aliados en el flamante organismo de Frente Único de que el Partido Comunista siendo partido era similar a los partidos burgueses, "sin querer reconocer la política de clases", criterio erróneo que había permitido la incorporación de elementos que eran "agentes activos de los partidos burgueses" 64 .

Este incidente era una expresión de la lucha por la hegemonía en el seno de la instancia de convergencia ya que la negativa a acordar una representación oficial al PCCh, adicional a la que ya tenía a través de sus cuadros sindicales, fue una respuesta al amplio predominio logrado por los comunistas (a través de la FOCH) a nombre de los trabajadores manuales al distribuirse la cuota de 450 delegados que correspondería al proletariado en la "Constituyente Chica", reflejado en las siguientes cifras: FOCH, 50 \% (225 congresales); Federación Ferroviaria, 10 \% (45 congresales); Federación Santiago Watt, 3 \% (12 congresales); Unión General de Metalúrgicos, $3 \%$ (14 congresales); Unión de Transportes Santiago, 1\% (5 congresales); Unión de Gásfiters, $1 \%$, (5 congresales); Unión Empapeladores y Similares 1 \% (5 congresales); Federación Obreros de Imprenta, 3 \% (12 congresales). El resto de la cuota obrera (28\%) se repartiría entre las organizaciones autónomas ${ }^{65}$.

A pesar de estas contradicciones y tensiones al interior del bloque popular, la propuesta de la Asamblea Constituyente de Asalariados e Intelectuales ganó numerosos

\footnotetext{
62 "En febrero próximo se verificará el Congreso Constituyente de Asalariados e Intelectuales", El Mercurio, Santiago, 5 de febrero de 1925; "Las actividades obreras alrededor del movimiento militar", Justicia, Santiago, 5 de febrero de 1925.

63 "Las actividades obreras alrededor del movimiento militar", op. cit.

64 “Actividades del Comité Ejecutivo Nacional”, Justicia, Santiago, 9 de febrero de 1925. ${ }^{65}$ Ibid.
} 
adeptos. A inicios de febrero, el Comité Ejecutivo Nacional Obrero emprendió una gira por las provincias del sur, consiguiendo formar subcomisiones en la mayoría de las capitales de provincia, en Talcahuano y la zona carbonífera ${ }^{66}$. Simultáneamente, comunistas y fochistas -las huestes mejor estructuradas y disciplinadas de la coalición- efectuaron numerosas asambleas y pequeños actos para agitar la exigencia de una política intransigente frente a la oligarquía conservadora, convocatoria a una Asamblea Constituyente y otras reivindicaciones muy sentidas. En numerosos puntos del país se crearon entidades que replicaban el Comité Nacional Obrero a nivel provincial o regional y en algunos lugares como Llanquihue- se realizaron convenciones regionales con participación de distintas fuerzas sociales y políticas. A fin de impedir transacciones a espaldas del pueblo que significaran la renuncia de los objetivos proclamados por los movimientos militares de septiembre y de enero, exigir el regreso inmediato de Alessandri y "una mano fuerte, enérgica e inflexible" que no cediera un punto en las conquistas obtenidas y supiera afianzarlas y consolidarlas definitivamente, el Comité Nacional Obrero convocó a manifestaciones en todo el país el 14 de febrero ${ }^{67}$. Luego del meeting realizado en Santiago, los dirigentes populares encabezados por Manuel Hidalgo en su calidad de presidente del Comité, entregaron el petitorio al presidente de la Junta de Gobierno, sumando a las demandas originarias de la convocatoria, entre otras, la exigencia de abstenerse de emplear la fuerza pública para reprimir los movimientos populares y cesar la concentración de tropas en la capital ${ }^{68}$.

La preparación de la Asamblea Constituyente de Asalariados e Intelectuales tomó un poco más de tiempo que el previsto en un inicio por sus impulsores: la fecha del 21 de febrero fue cambiada por la del 8 de marzo y la cantidad de participantes se elevó, a la postre, a 1.250 debido al gran interés que se manifestó en casi todo del país ${ }^{69}$. Cada uno de los grupos socioprofesionales (obreros, empleados, docentes, estudiantes, profesionales e intelectuales) inscribió por separado a sus delegados hasta completar el cupo que les fijó el Comité Nacional Obrero, resolviendo por sí mismo la distribución en el seno de su

\footnotetext{
66 "La Pequeña Constituyente", Justicia, Santiago, 10 de febrero de 1925; "La delegación del Comité Obrero Nacional", Justicia, Santiago, 16 de febrero de 1925; Babeuf, "Lota. Ecos de la jira hecha por el Comité Nacional Obrero", Justicia, Santiago, 21 de febrero de 1925.

67 "Un manifiesto del Comité Obrero Nacional", Justicia, Santiago, 12 de febrero de 1925; "Manifiesto del Comité Obrero Nacional", El Sur, Concepción, 12 de febrero de 1925; "La conspiración de la oligarquía santiaguina", El Comunista, Antofagasta, 13 de febrero de 1925; "La Gran Asamblea de anoche de obreros e intelectuales. Se forma el Comité Obrero Rejional”, La Jornada Comunista, Valdivia, 13 de febrero de 1925; "La obra del Comité Obrero Nacional", Justicia, Santiago, 14 de febrero de 1925; "La Convención regional de Llanquihue pro-Asamblea Constituyente", La Jornada Comunista, Valdivia, 19 de febrero de 1925.

68 "Ayer se efectúa el comicio público organizado por el Comité Nacional Obrero", El Diario Ilustrado, Santiago, 15 de febrero de 1925; "El comicio organizado por el Comité Obrero Nacional”, Justicia, Santiago, 16 de febrero de 1925.

${ }^{69}$ Las cifras de delegados varían según las fuentes. A fines de febrero Los Tiempos y El Mercurio anunciaron que estos serían 1.500. Por su parte, un artículo publicado en Justicia pocos días después del término de la "Constituyente Chica", por uno de los activistas comunistas involucrado en el evento, señala que los convencionales inscritos fueron 1.250 siendo comunistas y fochistas solo 300, esto es, $25 \%$ del total. "El próximo Congreso de Asalariados e Intelectuales", Los Tiempos, Santiago, 25 de febrero de 1925; "El próximo Congreso de Asalariados", El Mercurio, Santiago, 26 de febrero de 1925; M.A.S.R. [Manuel A. Silva R.], "El grandioso triunfo del comunismo en la Asamblea Obrera e Intelectual", Justicia, 13 de marzo de 1925.
} 
categoría. La Junta Ejecutiva de la Asociación General de Profesores de Chile convino que la cuota del magisterio se distribuiría de este modo: $45 \%$ a la Asociación General de Profesores de Chile, $20 \%$ a los maestros secundarios, 5\% a los profesores primarios no organizados, $10 \%$ al profesorado especial, $10 \%$ al profesorado superior, $3 \%$ a los maestros de las escuelas normales, 2\% a la Asociación de Educación Nacional y 2\% a la Sociedad de Educación Primaria, más un porcentaje de 3\% no precisado en las fuentes. En cambio, las inscripciones de obreros, empleados, profesionales, intelectuales, artistas y estudiantes fueron declaradas libres, en estricto orden de presentación hasta llenar los respectivos $\operatorname{cupos}^{70}$. Esto, sin detrimento del porcentaje de delegados obreros acordado a la FOCH, encabezada por los siguientes dirigentes, todos ellos comunistas: Juan Flores Tapia (Tocopilla), Salvador Ocampo (Antofagasta), Manuel A. Silva (Quillota), Manuel López (Calera), Ramón Sepúlveda Leal y Carlos Flores Ugarte (Viña del Mar), Manuel Hidalgo (San Fernando y Tinguiririca), Roberto Salinas (Chimbarongo), Luis Saavedra y Daniel Yáñez (Chillán), José González (Lota), Luis V. Cruz (Buen Retiro), Pedro González (Lebu), Abraham Quevedo (Valdivia). Hidalgo, Salinas, Cruz y González, eran delegados indirectos. Los otros fueron nombrados y enviados directamente por los consejos fochistas de distintas localidades ${ }^{71}$.

Las inscripciones se realizaron inclusive la víspera de la inauguración de la magna asamblea, muestra inequívoca del entusiasmo suscitado en todas las categorías convocadas. Aparte los personajes ya mencionados y un numeroso contingente de obreros, educadores, estudiantes, empleados y un puñado de feministas, se apuntaron escritores como Pablo de Rokha y Antonio Acevedo Hernández (dramaturgo cercano al anarquismo), los pintores Julio Ortiz de Zárate y Benito Rebolledo, estudiantes como el ácrata Óscar Schnake, Julio Barrenechea, Alfredo Demaría, Eugenio González y Fidel Araneda Bravo, quien sería con posterioridad un conocido sacerdote, escritor e historiador, pedagogos como Amanda Labarca y Liberato Aedo, director de la Escuela Salvador Sanfuentes ${ }^{72}$. El penúltimo día (6 de marzo) formalizaron su registro 173 nuevos adherentes, entre ellos numerosos profesionales e intelectuales, algunos de los cuales, en lo venidero alcanzarían notoriedad en diversos campos de la cultura y la política, entre otros: Roberto Espinosa, economista, docente universitario, alessandrista sin militancia partidaria; Rodolfo Michels, ingeniero, exdiputado radical; Adolfo Jofré Rossel, abogado; Melquíades Galleguillos, dentista; Carlos Stuarts Ortiz, profesor de Estado; Miguel Retamal Farinot, abogado; Héctor Salazar, químico; Gustavo Bietsch, ingeniero; Enrique Campos, contador; Susana Baeza, intelectual; José Luis Osorio, abogado; Filarión Contreras, médico cirujano; Emilia Rider, publicista; León Palacios Olmedo, abogado; César Bunster, pedagogo y masón; Elena Caffarena, estudiante de Derecho y lideresa estudiantil; Jorge Jiles Pizarro, abogado, afiliado al Partido Radical; Lucía Jorquera, directora de sociedad femenina; Arturo Davis, abogado; Norberto Pinilla, pedagogo; Benjamín Espinoza, periodista; Óscar Toro, químico; Ramón Flores, contador; Francisco García, profesor ${ }^{73}$. Por su parte, el abogado radical y

\footnotetext{
70 “Congreso Constituyente de Asalariados e Intelectuales”, El Mercurio, Santiago, 6 de marzo de 1925.

71 "Asamblea Constituyente de Obreros e Intelectuales", Justicia, Santiago, 8 de marzo de 1925.

72 "La celebración de la Constituyente Chica", Las Últimas Noticias, Santiago 28 de febrero de 1925.

73 “En el Teatro Municipal se inaugurará mañana el Congreso de asalariados e intelectuales”, El Mercurio, Santiago, 7 de marzo de 1925.
} 
miembro del Comité Nacional Obrero Carlos Vicuña Fuentes, puso en circulación un Proyecto de Constitución de la República de Chile en el que, entre otros conceptos, se definía la misión del gobierno como la de "mantener el orden público, favorecer el progreso social, garantizar la libertad y proteger la vida de los habitantes, asegurar a todos el goce de sus bienes de acuerdo con las leyes, y satisfacer las necesidades generales de la colectividad en el orden industrial, jurídico, moral, intelectual y de salubridad y de bienestar"74.

Con todo, la Asamblea se vio mermada antes de su inauguración porque algunas organizaciones sociales importantes decidieron mantenerse al margen, entre ellas, nada menos que la Federación de Obreros de Imprenta (FOI), bajo influencia anarcosindicalista. Luego de una discusión, esta institución estimó que su declaración de principios "esencialmente sindicalista y revolucionaria a base de acción directa", le impedía participar en "actos que afianzaran el actual régimen capitalista", a lo que se sumaba el hecho que el Comité Nacional Obrero hubiese excluido a los sindicatos antiestatales. Por ello la Junta Central de la FOI recomendó a sus asociados la no participación en la "Constituyente Chica"75. Algunos sectores ácratas fueron aún más incisivos, criticando con aspereza a aquellos anarquistas que se sumaron a esta Asamblea. José Federico Cortés, desde las columnas del periódico libertario iquiqueño El Surco, acusó a Triviño, Baloffet y otros cercanos a la IWW de defender el "cuartelazo", negándoles la calidad de "compañeros". En Santiago, Tribuna Libertaria y que el afamado exvicepresidente de la FECH Juan Gandulfo, también reprendieron con severidad a sus correligionarios implicados en el ejercicio constituyente ${ }^{76}$. Desde las columnas de Claridad, órgano de la Federación de Estudiantes, Gandulfo espetó:

¿A dónde van algunos sedicentes anarquistas propiciando una Asamblea Constituyente y participando en los debates de las asambleas políticas? ¿No significa toda esta acción el abandono de los postulados revolucionarios y el desahucio del valor de las organizaciones obreras como entidades capaces de afrontar por sí solas los problemas sociales? ${ }^{77}$.

\section{Los debates de la Asamblea Constituyente de Asalariados e Intelectuales}

El gran congreso popular fue inaugurado, con una concurrencia de más de 2.000 personas, a las 10,35 h de la mañana del domingo 8 de marzo en el Teatro Municipal de Santiago mediante un discurso pronunciado por el comunista Manuel Hidalgo en su calidad de cabecilla del Comité Nacional Obrero. En su alocución, el veterano luchador explicó el sentido del ejercicio que realizarían durante tres días los delegados provenientes de distintos puntos del país:

\footnotetext{
74 "La Constituyente Chica del próximo Domingo", La Jornada Comunista, Valdivia, 5 de marzo de 1925.

75 "Junta Central de la Federación de Obreros de Imprenta de Chile (Versión oficial)", El Diario Ilustrado, Santiago, 7 de marzo de 1925.

${ }^{76}$ Ignacio Bastías, "Política libertaria y movimiento anarquista en Santiago, 1917-1927”, tesis para obtener el grado de Licenciado en Historia, Santiago, Universidad de Chile, 2007, pág. 53; Víctor M. Muñoz C., Armando Triviño: Woobblie. Hombres, ideas y problemas del anarquismo en los años veinte. Vida y escritos de un libertario criollo, Santiago, Editorial Quimantú, 2009, págs. 38 y 39.

77 J. Gandulfo, "Mangoneo y colaboracionismo reformista”, Claridad, Nº130, Santiago, mayo de 1925.
} 
Nos reunimos en esta ocasión los débiles para imponer las normas de justicia y de igualdad social que han de regir a la sociedad futura contra la omnipotente voluntad de los privilegiados de la injusta organización de la sociedad contemporánea.

Durante un siglo hemos ensayado sistemas de gobierno desde el absolutismo presidencial, último resabio de los regímenes monárquicos, hasta la absurda parodia de un parlamentarismo enervante y disociador que ahogó en la orgía de las disensiones bizantinas todo germen de progreso y de bienestar. La asamblea de hoy lleva envuelta en su esencia la firme voluntad de reparar los graves daños que han hecho a la República estos sistemas de gobierno, basadas todos en la escuela liberal, para encaminar la nueva organización del Estado sobre los principios de la escuela socialista que, dará al mundo fraternidad, justicia e igualdad social ${ }^{78}$.

Hidalgo desarrolló sus ideas mediante una curiosa alternancia de roles, a ratos en tanto presidente del conglomerado amplio promotor del evento (como se refleja en el párrafo anterior) y, en otros pasajes, asumiendo con desenvoltura su calidad de dirigente del PCCh:

Así, para nosotros los comunistas que aspiramos a realizar integralmente el socialismo, porque entendemos que esta es la única fórmula de afirmar la justicia y la igualdad humana, nuestra misión en esta asamblea es la de demostrar esta verdad frente a los que solo aspiren a afianzar la libertad con las pomposas declaraciones que encierran las legislaciones escritas o con los que creen en la acción limitada que corresponde al Estado, dentro de las relaciones entre el capital y el trabajo ${ }^{79}$.

Esta referencia a la principal fuerza política estructurada en el seno de la "Constituyente Chica" fijó el tono de los enfrentamientos ideológicos y partidarios que se desarrollarían a continuación. Luego de varios discursos, un acto en apariencia tan simple como la elección de la mesa directiva del congreso se prolongó hasta bien avanzada la tarde del primer día de sesiones. Al finalizar, luego de intensas discusiones y transacciones entre distintos grupos, se eligió como presidente del congreso a Víctor Troncoso, de la Asociación General de Profesores; primer vicepresidente a Carlos Alberto Martínez, presidente de la Asociación de Sociedades Mutualistas de Santiago; segundo vicepresidente a Roberto Meza Fuentes; y secretarios a Alfredo Montecinos, Ángel Mella, Luis Ayala, Daniel Naveas, Fernando Celis y el estudiante José Lafuente ${ }^{80}$. La conformación de esta

\footnotetext{
78 "La Asamblea Constituyente. Discurso del Presidente del Comité Obrero Nacional”, Justicia, Santiago, 9 de marzo de 1925.

${ }^{79}$ Ibid.

80 "Ha dado comienzo a sus labores el Congreso Constituyente de Asalariados e Intelectuales", El Mercurio, Santiago, 9 de marzo de 1925, "El Congreso de Intelectuales y Asalariados se inauguró ayer en le [sic] Teatro Municipal”, El Diario Ilustrado, Santiago, 9 de marzo de 1925; "El Congreso Constituyente de Asalariados e Intelectuales ha iniciado ayer sus labores", El Mercurio, Valparaíso, 9 de marzo de 1925; "Santiago: La inauguración de la Constituyente Chica", La Jornada Comunista, Valdivia, 10 de marzo de 1925; "Asamblea Constituyente de obreros e intelectuales" El Comunista, Antofagasta, 24 de marzo de 1925. Los otros cargos de la Asamblea fueron los siguientes: relatores: César Godoy Urrutia, Luis Gómez C., Guillermo Aparicio, Genaro Torres, Carlos Pellegrini, Alejandro Escobar y Carvallo; comisión informante: Oscar Fontecilla, Luis Víctor Cruz, Gregorio Guerra, Ramón Jerez, Honorio Henríquez Pérez, Salvador Barra Woll, Ramón Escuti,
} 
mesa significaba una derrota táctica para los comunistas quienes hicieron sentir su desagrado por medio del rechazo de Luis Víctor Cruz a la primera vicepresidencia que la mayoría de la sala le había ofrecido ${ }^{81}$. A fin de calmar los ánimos ya un tanto caldeados, Víctor Troncoso manifestó que no debía haber en la asamblea mayoría ni minoría sino "tranquilidad, tino, cordura y ausencia de suspicacia". De esto dependería el éxito ${ }^{82}$.

Pocas mociones concitaron consenso general: un homenaje a Luis Emilio Recabarren, la supresión de las apuestas mutuas en los hipódromos y la separación de la Iglesia y del Estado con confiscación de los bienes religiosos fueron aprobadas por aclamación. Otras proposiciones como el combate contra el militarismo a fin de conseguir la disolución del Ejército, la supresión del servicio militar obligatorio y su reemplazo por una ley de trabajo militar obligatorio, la prohibición de los empresarios vinícolas de formar parte del futuro Congreso Nacional quedaron pendientes para ser consideradas por la comisión informante. Una propuesta de envío de un telegrama de adhesión a Alessandri fue rechazada porque la mayoría de la asamblea consideró que se debía actuar con entera libertad ${ }^{83}$.

La discusión más importante de ese primer día fue la que se produjo luego del discurso del anarquista Alberto Baloffet, quien postuló que los proletarios no debían abocarse a redactar una nueva Constitución, tan solo debían fijar ciertos principios generales que reflejaran sus intereses. Carlos Vicuña Fuentes lo refutó sosteniendo la necesidad de escribir un proyecto de Constitución, pues consideraba que era necesario establecer clara y precisamente una serie de cuestiones, como las facultades del Presidente de la República, a fin de evitar la invasión de atribuciones del Jefe de Estado por el Parlamento. Luego de un acalorado debate en el que también intervinieron el anarcosindicalista Armando Triviño y los comunistas Castor Vilarín y Abraham Quevedo, se aprobó por gran mayoría la moción de Baloffet, que establecía que los acuerdos tendrían "carácter de principios generales" por considerar que no era "de interés de la clase productora elaborar una constituyente política" "84: "El Congreso de Asalariados e

Carlos Contreras Labarca, Galvarino Gil, Ramón Sepúlveda Leal, Manuel Hidalgo, Manuel A. Silva, Carlos Vicuña Fuentes, Santiago Lazo, Héctor Álvarez, Domingo Rivera Parga, Domingo A. Garfias, el expresidente de la FECH (1920-1921) y filoanarquista Alfredo Demaría, Roberto Espinoza, Pedro León Ugalde, Carlos A. Sepúlveda y Amanda Labarca Hubertson.

81 "Ha dado comienzo a sus labores el Congreso Constituyente de Asalariados e Intelectuales", op. cit.

82 "El Congreso de Intelectuales y Asalariados se inauguró ayer en le [sic] Teatro Municipal", op. cit.

${ }^{83}$ Ibid.; "Más de mil convencionales asistieron al Congreso Constituyente de Asalariados e Intelectuales inaugurado ayer", El Sur, Concepción, 9 de marzo de 1925; "El Congreso de Intelectuales y Asalariados se inauguró ayer en le [sic] Teatro Municipal", op. cit.; "Las labores de la Constituyente Chica", La Jornada Comunista, Valdivia, 11 de marzo de 1925; "Asamblea Constituyente de obreros e intelectuales", El Comunista, Antofagasta, 25 de marzo de 1925.

84 "El Congreso Constituyente de Asalariados e Intelectuales ha iniciado ayer sus labores", op. cit.; "Ha dado comienzo a sus labores el Congreso Constituyente de Asalariados e Intelectuales", op. cit.; "El Congreso Constituyente de Asalariados e Intelectuales ha iniciado ayer sus labores", El Mercurio, Valparaíso, 9 de marzo de 1925, "En el Congreso de asalariados e intelectuales", El Sur, Concepción, 10 de marzo de 1925; "Algunos extractos sobre las labores de la Constituyente Chica", La Jornada Comunista, Valdivia, 15 de marzo de 1925. 
Intelectuales se pronunciará solamente sobre principios generales y desechará todo proyecto de Constitución" 85 .

Por intermedio de la FOCH, los comunistas presentaron una moción en la que se declaraba que el proletariado concurriría a la futura Asamblea Constituyente a fin de "hacer la crítica más inexorable y justa contra el capitalismo y sus medios de explotación y de opresión" para continuar preparando el advenimiento de "una organización fundada en los principios de las doctrinas socialistas, sin renunciar, por consiguiente, al derecho de reemplazar en el instante oportuno las armas de la crítica por la crítica de las armas". El proletariado debía, pues, usar como táctica para su liberación la lucha de clases y la revolución social hasta tomar el poder, luego de lo cual debía establecer su dictadura durante un "período transitorio" para "dominar a las fuerzas contrarrevolucionarias y organizar racionalmente la producción" "86. Una declaración de este tipo, que implicaba la exposición completa del programa estratégico comunista, sin consideración táctica alguna en vistas de la cohabitación con sus aliados, no podía sino generar una de las disputas más arduas que se desarrollarían en los días sucesivos en la Asamblea.

Otro tema -menos polémico que el anterior- que ocupó a los delegados durante la jornada del 8 de marzo, fue el referido la emancipación de la mujer. La vocera de la Federación Femenina, María Teresa Urbina Contreras, pronunció un discurso criticando a aquellos hombres que se habían "encargado de deprimir la condición social de la mujer en la vida, olvidando de un modo absurdo su importante misión progenital [sic] y educadora eximia". Había, sostuvo esta feminista, que dar a la mujer sus plenos derechos y garantías al igual que el hombre, puesto que, "como este, y quizás más que él”, ella tenía derecho a intervenir en la dirección de la sociedad ${ }^{87}$ :

No es aceptable -dijo- que los hombres de este siglo, llamado el siglo de las luces, mantengan a la mujer en el estado de abyecta esclavitud en que vegetó en la edad antigua y media. La mujer es la base fundamental de la humanidad, ella educa y prepara al hombre en la lucha por la existencia: ella es la que ha formado lo poco de noble y de bueno que tiene y, por lo tanto debe ser respetada y admirada como la madre excelsa de la humanidad ${ }^{88}$.

Al término de su aplaudida alocución Urbina hizo un llamado solemne para que los intereses de su género fueran tomados en cuenta por el conglomerado popular:

Yo vengo a levantar la voz en esta asamblea en representación de mi sexo, para pedir que en los proyectos constitucionales que aquí van a laborar, se le reconozca sus derechos, y se le marque un sitio de lucha y de labor en las filas que marchan hacia la cima del progreso del país, que debe culminar en el perfeccionamiento humano ${ }^{89}$.

\footnotetext{
85 “Ayer continuó sus sesiones el Congreso Constituyente de Intelectuales y Asalariados", El Mercurio, Santiago, 10 de marzo de 1925.

86 "Algunos extractos sobre las labores de la Constituyente Chica”, La Jornada Comunista, Valdivia, 15 de marzo de 1925.

87 "Ha dado comienzo a sus labores el Congreso Constituyente de Asalariados e Intelectuales", op. cit.

88 "Algunos extractos sobre las labores de la Constituyente Chica", La Jornada Comunista, Valdivia, 14 de marzo de 1925.

89 "Ha dado comienzo a sus labores el Congreso Constituyente de Asalariados e Intelectuales", op. cit.
} 
Las sesiones del lunes 9 de marzo fueron tan o más tumultuosas que las de la jornada anterior. Solo hubo unanimidad para aprobar el saludo fraternal a todos los presos que yacían en las cárceles del mundo entero "por el noble delito de pensar y obrar libremente", propuesto por Baloffet, y el punto cuarto del informe de comisión estableciendo que: "La propiedad es social en su origen y en su destino. La propiedad de la tierra y de los instrumentos de producción y cambio, debe estar socializada" ". Luego de acordar una petición al gobierno de cancelación de la personería jurídica de los centros sociales que vendieran bebidas alcohólicas, los convencionales se enfrascaron en discusiones más tensas y profundas. Tras largo debate, se decidió que el problema principal del momento era la elaboración de una nueva Carta Fundamental que consultara "las aspiraciones nacionales y no la simple reforma de la Constitución derogada el día 5 de septiembre último" "91. Acto seguido se leyó una indicación firmada por los anarquistas Armando Triviño, Alberto Baloffet, Miguel Ruz y Quiterio Chávez, en la que se pedía la abolición de la propiedad privada y del principio de autoridad que la sostenía ${ }^{92}$.

Baloffet denunció la acción de algunos políticos que querían "desviar los fines de la asamblea para hacer aprobar una Constitución, la que tomarían más tarde como plataforma política para servir sus intereses y ambiciones", insistiendo en que la asamblea no se pronunciara sobre un proyecto de Constitución, sino sobre principios esenciales. Vicuña Fuentes "expresó su pena por los conceptos y recriminaciones" que había merecido la comisión informante, defendiendo la idea de redactar una Constitución ${ }^{93}$. Una información de prensa describió en los siguientes términos el desarrollo que entonces tomó esta sesión:

A continuación se produjo un acalorado debate en que tomó parte gran número de asambleístas, protestando del proceder de la mesa por cuanto se estimaba poco imparcial. Restablecida después la calma en la asamblea, usan de la palabra los señores Manuel Hidalgo, para defender a la comisión, Ruz, Ramón Sepúlveda Leal, que expresa su protesta por la forma de que se han valido algunos elementos para llegar a la tribuna y que rechaza el punto de la socialización.

El señor Carlos Vicuña Fuentes, habló a continuación, para decir que en el punto aprobado el día anterior sobre separación de la Iglesia y del Estado, y confiscación de sus bienes 'habría mucho de injusticia, de atropello y de impolítico en confiscar los bienes a la Iglesia, porque se la acusa de enviar riquezas al exterior, iipues con el mismo criterio se debería pedir la confiscación de las compañías mineras yankees, que exportan todas sus riquezas!!"94.

Luego de esta impensada defensa de los intereses de la Iglesia Católica por parte de un militante del Partido Radical, se dio lectura al voto propuesto por Vicuña Fuentes y sus

\footnotetext{
90 “Ayer continuó sus sesiones el Congreso Constituyente de Intelectuales y Asalariados”, op. cit.; "Las actuaciones de la mañana del Congreso de Asalariados e Intelectuales”, Las Últimas Noticias, Santiago, 10 de marzo de 1925.

${ }^{91}$ Ibid.; "La Constituyente de Asalariados e Intelectuales", Justicia, Santiago, 11 de marzo de 1925.

92 "La Constituyente de Asalariados e Intelectuales", op. cit.

93 “Ayer continuó sus sesiones el Congreso Constituyente de Intelectuales y Asalariados”, op. cit.

${ }^{94}$ Ibid.
} 
correligionarios Héctor Álvarez, Santiago Lazo y Amanda Labarca para ser enviado a comisión:

Los suscritos partidarios de la separación de la Iglesia y del Estado, no aceptamos sin embargo extorsión alguna contra la Iglesia ni menos la confiscación de sus bienes, los cuales deben quedar sometidos al futuro común. Y en este sentido pedimos la reconsideración del acuerdo que establece dicha confiscación ${ }^{95}$.

Al dar cuenta de esta insólita moción de los inveterados anticlericales y "come frailes" radicales a favor de la Iglesia, el periódico comunista-fochista diría con saboreada satisfacción que dicha declaración lapidaba a perpetuidad a algunos liberales, y aún más al radical positivista Vicuña: "No sabe el público cómo estimar a veces a ciertos figurones, que en el ánimo de ser las estampas de toda idea, no sustentan a firme y con convicción ninguna. A estos se les puede llamar muy bien los equilibristas de la cuerda floja" 96 .

La lectura del punto del informe de comisión afirmando que "los hombres y las mujeres gozarán de igual capacidad política y civil”, provocó -según reporteó El Mercuriouna brillante defensa de la señora María de Hidalgo ${ }^{97}$. Eduvigis de Villar, dirigente del Partido Demócrata Femenino, apoyó la indicación formulada por la comisión. Enseguida habló Víctor Arauco, del Consejo de la Construcción de la FOCH de Temuco, quien se manifestó partidario de la indicación en principio, sin embargo, consideró que "como un hecho fatal, la mujer estaba condenada a no poder usar de los derechos políticos, porque estima que aún no se ha liberado espiritualmente"98. Amanda Labarca, a quien "se le escuchó con tolerancia", afirmó que "aún cuando actualmente a la mujer no la creían capaz de obrar libremente en igualdad de condiciones con el hombre, la asamblea debía mirar hacia el futuro" y aprobar que se le concediera el voto a la mujer ${ }^{99}$. La votación sobre este importante asunto quedó pendiente para el día siguiente.

La tercera jornada -martes 10 de marzo- fue tan o más agitada que la anterior, pero al mismo tiempo, más productiva. La cuestión femenina suscitó una acalorada discusión en que participaron, por una parte, Bertina Pérez, dirigente del Partido Demócrata Femenino; Berta Recabarren, fundadora del Partido Cívico Femenino y futura asistente social; Isabel Díaz, activista comunista y representante del Consejo Femenino de la FOCH y el concejal comunista por Viña del Mar Ramón Sepúlveda Leal; por la otra parte, un convencional de

\footnotetext{
95 Ibid. Véase también "La Asamblea Constituyente de Asalariados e Intelectuales", Los Tiempos, Santiago, 12 de marzo de 1925.

96 "La Constituyente de Asalariados e Intelectuales", op. cit.

97 "Ayer continuó sus sesiones el Congreso Constituyente de Intelectuales y Asalariados”, op. cit. María de Hidalgo era militante comunista, cónyuge de Manuel Hidalgo. Pocos después de estos debates, a fines de marzo, María junto a su correligionaria Isabel Díaz y las feministas Berta R. de Abadie, Francisca Robles y Lidia M. de Escobar, sería promotora de un Frente Único Femenino, organismo amplio destinado a luchar por los derechos de las mujeres. La Secretaria, "La igualdad de derechos de ambos sexos", Justicia, Santiago, 11 de abril de 1925.

98 "La Constituyente de Asalariados e Intelectuales", op. cit.

99 “Ayer continuó sus sesiones el Congreso Constituyente de Intelectuales y Asalariados”, op. cit.
} 
apellido Alvear y el demócrata Fernando García Oldini, aprobándose, finalmente moción que establecía que hombres y mujeres gozarían de "igual capacidad política y civil""100.

La discusión acerca del tipo de Estado - unitario o federal- fue más tranquila. El informe de mayoría sostenía que "la República de Chile será federal", mientras que el de minoría propiciaba la "descentralización administrativa funcional" dentro de régimen unitario de gobierno. Los partidarios de la descentralización administrativa impugnaron el régimen federal, manifestando que había fracasado en todos los países en que se había aplicado, en tanto que los partidarios del federalismo aseveraron, por su parte, que este sistema facilitaba las actividades del pueblo ${ }^{101}$. Llevado a votación la noche de ese tercer día de sesiones, la "Constituyente Chica" adoptó la fórmula federalista y en el preámbulo de su declaración de principios dejó estipulado que "el gobierno político de la República" tendría por objeto "coordinar y fomentar la producción económica y todas aquellas actividades que tienden al mejoramiento de la sociedad dentro del territorio nacional"102.

Otro acuerdo de trascendencia -uno de los que daría su sello particular a este congreso- fue la idea de hacer residir el Poder Legislativo en una "Cámara Funcional" cuyos miembros serían elegidos "por los gremios organizados del país" en base a un mandato "siempre revocable" 103 .

Del mismo modo reposado se decidió que la administración de justicia debía ser gratuita, que las magistraturas del Estado debían ser colegiadas y generarse mediante elecciones restringidas a las clases productoras. Igualmente hubo amplio acuerdo en solicitar al Ejecutivo la prohibición de la exportación de cereales y suprimir los derechos aduaneros para los artículos alimenticios de primera necesidad ${ }^{104}$.

La polémica ideológica sobre regímenes sociales se transformó en un violento enfrentamiento verbal entre los comunistas, la delegación del magisterio y otras organizaciones. La propuesta formulada por un maestro asegurando que la Asociación de Profesores de Chile "en la lucha por la reivindicaciones sociales no acepta ni aceptará tiranía alguna, incluso la proletaria"105, concitó la hostilidad de los comunistas, produciéndose un gran desorden y violentos intercambios de palabras entre los bandos rivales. Luego de restablecido el orden, un amplio sector declaró que las Sociedades Unidas de Chile -institución que aseguraba representar a setenta y cinco sociedades autónomas ${ }^{106}$ adhería "entusiastamente a la Asociación General de Profesores de Chile"107. No obstante este pronunciamiento y el de otros actores presentes en el teatro, ninguna fracción logró

100 “Acuerdos adoptados ayer por Congreso Constituyente de Asalariados e Intelectuales", El Mercurio, Santiago, 11 de marzo de 1925.

101 Ibid.

102 Ibid.

103 "Interesantes mociones aprobadas ayer por 'la Constituyente Chica'“،, Las Últimas Noticias, Santiago, 11 de marzo de 1925.

${ }^{104}$ Salazar, Del poder constituyente..., op. cit., pág. 84.

105 “Acuerdos adoptados ayer por Congreso Constituyente de Asalariados e Intelectuales”, op. cit.

${ }^{106}$ La representatividad de este conglomerado fue fuertemente cuestionada por los comunistas y fochistas. Según el periódico antofagastino El Comunista, "eso de las sociedades unidas es un bluff, pues solo les queda el nombre y en cada una de ellas no militan más de diez o veinte mutualistas. Son por el estilo del Congreso Social Obrero que existe aquí". "Noticias de Santiago: De la constituyente chica", El Comunista, Antofagasta, 13 de marzo de 1925.

107 “Acuerdos adoptados ayer por Congreso Constituyente de Asalariados e Intelectuales", op. cit. 
imponer sus posiciones. El debate terminó en un catastrófico empate ya que el clima generado hacía cada vez más difícil los acuerdos en el poco tiempo que faltaba para el cierre de la magna asamblea popular.

La cuestión educacional también fue objeto de encendidas discusiones. Pese a que el proyecto de acuerdo presentado por los Comités Ejecutivos de la $\mathrm{FOCH}$, de la Unión de Empleados de Chile, de la Asociación General de Profesores y la FECH, señalando que el Congreso Constituyente resolvía "hacer suyos y exigir del Gobierno el pronto despacho de los proyectos de reforma educacional auspiciados por la Asociación de Profesores y por la Federación de Estudiantes", fue aprobado por unanimidad ${ }^{108}$, los temas de fondo relacionados con la concepción de la educación revelaron, una vez más, las profundas diferencias ideológicas existentes entre los distintos sectores del Congreso de Asalariados e Intelectuales.

Los debates más virulentos se produjeron el cuarto y último día de sesiones miércoles 11 de marzo- porque en esta jornada debían definirse cuestiones fundamentales que no habían podido ser zanjadas en las anteriores.

Hubo sí, algunos temas que concitaron amplio acuerdo, como una moción propiciando un saludo fraternal a los pueblos que conformaban la Unión Soviética; otra que declaró que la futura Asamblea Constituyente Nacional debía "generarse con representantes de todas las fuerzas vivas de ambos sexos, dando al elemento asalariado la mayoría de la representación que le corresponde en justicia, a fin de que los postulados de redención social obtengan dentro de ella la confirmación legal que reclaman la nación"109; una tercera demandando al gobierno "atención preferente hacia la raza aborigen", sumida en "deplorable y abandonaba situación"; además de algunas peticiones de orden gremial y social $^{110}$, los temas restantes resultaron mucho más espinudos.

El preámbulo del enfrentamiento final entre las tendencias opuestas en el seno de la "Constituyente Chica" se dio con motivo de la discusión sobre el organismo encargado de continuar la lucha por el triunfo de los principios aprobados. Había quienes, como los comunistas y algunos aliados, proponían confiar esta tarea al Comité Obrero Nacional. Otros sectores, en su mayoría maestros, entre los cuales se observaba una difusa influencia anarquista, además del Partido Radical, se oponían de manera decidida a ello ${ }^{111}$. Un miembro de la asociación gremial de los docentes sostuvo que el Comité Nacional Obrero había degenerado en un cuerpo político, por lo que debía dejar de existir al término del Congreso y propuso que mientras todas las organizaciones participantes no ratificaran los

${ }^{108}$ Ibid.; "El Congreso de Asalariados e Intelectuales clausuró sus labores, dejando despachadas numerosas declaraciones", El Sur, Concepción, 13 de marzo de 1925.

109 "Ayer da fin a sus labores el Congreso Constituyente de Asalariados e Intelectuales", El Mercurio, Santiago, 12 de marzo de 1925.

${ }^{110}$ Ibid.

${ }^{111}$ Según Ana María Contador, la influencia anarquista en el organismo gremial de los maestros se limitaba a la difusión de sus postulados en el periódico gremial Nuevos Rumbos, a la realización de conferencias en los "hogares sociales" y al apoyo de la IWW a las campañas del profesorado. El rechazo a los partidos políticos que se evidenciaba en la Asociación General de Profesores, más que reflejar una adscripción ideológica a la corriente libertaria, era un reflejo de su decepción frente a las maniobras parlamentarias que habían perjudicado las huelgas del magisterio en 1912 y 1922. Ana María Contador, "La Asociación General de Profesores de Chile: 1922-1928", tesis para optar al grado de Licenciada en Historia, Santiago, Universidad de Chile, 1986, págs. 47-56. 
acuerdos no debía nombrarse ningún cuerpo. Esa sería la actitud que asumiría su institución: la Asociación General de Profesores discutiría in extenso los acuerdos aprobados y no prestaría su cooperación a ningún comité que derivara en acción política. Al finalizar, ya al anochecer, luego de largas discusiones y negociaciones de pasillo, se acordó "crear un organismo encargado de propagar los principios aprobados por la Constituyente y agitar intensamente la opinión para hacer que ellos triunfen". Este se formaría por un delegado (presidente o secretario general) de cada una de las principales entidades presentes en la "Constituyente Chica": Asociación General de Profesores, FOCH, FECH, Unión de Empleados, Federación Ferroviaria, sociedades autónomas, más una persona nombrada por la misma asamblea ${ }^{112}$.

Comunistas y fochistas de una parte, maestros, estudiantes y empleados por otra, se enfrentaron con rudeza a propósito de dos informes referidos a la cuestión de la educación presentados por la comisión informante. El informe de mayoría era apoyado por los comunistas y el de minoría por los otros grupos mencionados. Varias votaciones resultaron empatadas a simple vista, pues se realizaban levantando la mano. La decisión del presidente de recoger las tarjetas de la mayoría y enseguida las de los partidarios del informe de minoría provocó enérgicas protestas de maestros, estudiantes y empleados. En vista de lo ocurrido, a fin de impedir un quiebre definitivo, Barra Woll, a nombre de los comunistas, declaró que su sector se plegaba al voto de minoría, aprobándose de este modo la moción que señalaba:

La finalidad de la enseñanza es capacitar al productor para que cada hombre sea capaz de bastarse a sí mismo económicamente y dar al hombre una cultura desinteresada que lo dignifique y lo haga amar y comprender la verdad, el bien y la belleza. El Estado debe proporcionar los fondos para la enseñanza pública, que será gratuita desde la escuela primaria hasta la Universidad. Deben dirigir la enseñanza en sus planes y orientaciones los Consejos de maestros, padres y estudiantes.

La única intervención del Estado en enseñanza pública es la de proporcionarle fondos para que esta realice sus propios fines y ejercer el control solo en la capacidad técnica de los educadores, respetando en forma absoluta, la libertad de la cátedra y el espíritu del magisterio ${ }^{113}$.

En este contexto enrarecido por las agrias polémicas, recriminaciones y descalificaciones mutuas entre el sector comunista-fochista y sus variopintos contradictores (profesores, radicales, demócratas, anarquistas, sindicalistas sin partido, etc.) era imposible llegar a mayores acuerdos. Bastante avanzada la noche de esta cuarta afiebrada jornada, el presidente "accidental" de la Federación de Estudiantes y vicepresidente del Centro de Propaganda Radical Enrique Rossel, pronunció las palabras de cierre de la Asamblea de Asalariados e Intelectuales:

\footnotetext{
112 Ibid.; "El Congreso de Asalariados e Intelectuales clausuró sus labores, dejando despachadas numerosas declaraciones", op. cit.

113 "Ayer da fin a sus labores el Congreso Constituyente de Asalariados e Intelectuales", op. cit.; "El Congreso de Asalariados e Intelectuales clausuró sus labores, dejando despachadas...”, op. cit.
} 
Los estudiantes hemos estado con ustedes los obreros en todos los difíciles momentos y es por esto que tenemos el deber de hablaros con sinceridad y es por esto que vosotros tenéis el deber de oírnos. Vemos con profunda pena que en esta asamblea se haya obedecido ciegamente a un Comité Político determinado que ha levantado la mano para imponer acuerdos y tras él ha seguido parte de la asamblea predispuesta con anterioridad a acatar ciegamente a este Comité Político. Esto nos da profunda pena ${ }^{114}$.

La mención del "comité político" que habría prefabricado ciertos acuerdos contando para ello con el seguimiento automático y ciego de una parte de los delegados era una alusión clara y directa a la dirección del PCCh y al bloque comunista-fochista, a quienes se acusaba haber respondido como cuerpo, de manera mecánica e irreflexiva, a la orden de una voz de mando ${ }^{115}$. La reacción de los aludidos fue instantánea: Rossel fue interrumpido a viva voz, originándose una gran algarada, que no fue posible controlar ${ }^{116}$. Un órgano de prensa capitalino dio cuenta en estos términos del desenlace de la asamblea de asalariados e intelectuales:

El debate fue acalorándose más y más en las dos votaciones preliminares. Llegó un momento en que los profesores, empleados y estudiantes expresaron sus deseos de retirarse de la sala, oyéndose voces como la de los señores Rossel y Barrenechea que expresaron que la Convención era solamente una mascarada.

En esos instantes, subió a la tribuna el señor Barra Woll, quién expresó que aceptaba, en nombre de los comunistas, el informe de minoría, a fin de no quebrar la unidad del Congreso.

El término del Congreso fue un tumulto en que nadie se daba cuenta de nada. El presidente en ejercicio de la Federación de Estudiantes, señor Rossel pronunció un discurso exponiendo que los estudiantes se sentían traicionados por la actitud observada por los elementos obreros, que habían en todo instante obedecido a las indicaciones de los leaders de determinado partido. En este instante, el presidente señor Fontecilla se levantó de la mesa directiva e increpó duramente al orador. Igual cosa hizo el conocido dirigente comunista señor Barra Woll. La sala era un volcán y los gritos no dejaban oír palabra alguna... Daban las doce, y la policía, en cumplimiento de órdenes superiores, despejaba la sala. Así terminó el Congreso de Asalariados e Intelectuales ${ }^{117}$.

\footnotetext{
114 "Ayer da fin a sus labores el Congreso Constituyente de Asalariados e Intelectuales", op. cit.

${ }^{115}$ Poco después de la clausura de la "Constituyente Chica", una voz autorizada del PCCh respondió a las críticas formuladas en un artículo del dirigente de los empleados Gregorio Guerra. El joven abogado comunista Carlos Contreras Labarca sostuvo que Guerra había olvidado que los obreros fochistas se hallaban no solo adheridos a una doctrina, sino además sometidos a una disciplina. "Que a fin de realizar en el Congreso una labor útil y armónica, se pusieron de acuerdo previamente acerca de un programa determinado; y que con arreglo a él votaron invariablemente. Lo censurable -agregó- sería que hubieran votado contra ese programa". Carlos Contreras Labarca, "Una polémica que debe terminar", Justicia, Santiago, 17 de marzo de 1925.

116 "Ayer da fin a sus labores el Congreso Constituyente de Asalariados e Intelectuales", op. cit.

117 "Con una borrascosa sesión terminó anoche el Congreso de asalariados e Intelectuales", Las Últimas Noticias, Santiago, 12 de marzo de 1925.
} 
De un modo imprevisto, con menos acuerdos que los esperados, en medio de un clima agrio y de gran tensión, concluyó la Asamblea Constituyente de Asalariados e Intelectuales, sin haber cumplido su objetivo inicial de dotar de un borrador de Constitución Política del Estado que aunara las aspiraciones de los trabajadores en la perspectiva del gran debate nacional que se desarrollaría cuando Alessandri Palma convocara a la "Constituyente Grande" de todas las clases y sectores sociales del país.

\section{Los resultados de la "Constituyente Chica"}

Con todo, los delegados lograron compromisos mínimos que se tradujeron en grandes lineamientos constitucionales que reflejaban los principales anhelos del movimiento obrero y popular. Estos principios se enarbolaron como una suerte de programa común a ser defendido en la futura Asamblea Constituyente Nacional:

El Congreso de Asalariados e Intelectuales declara: que la Asamblea Constituyente encargada de crear la nueva organización política del país, debe generarse con representantes de todas las fuerzas vivas de ambos sexos, dando al elemento asalariado la mayoría de la representación que le corresponde en justicia, a fin de que los postulados de redención social obtengan dentro de ella la confirmación legal que reclama la nación.

El Congreso Constituyente de Asalariados e Intelectuales acuerda que los siguientes principios deben servir de base a la Constitución Política de la República de Chile, a fin de poner al alcance de todos los beneficios de la justicia.

El Gobierno político de la República tiene por objeto coordinar y fomentar la producción económica y todas aquellas actividades que tienden al mejoramiento de la sociedad dentro del territorio nacional.

La tierra es propiedad social en su origen y en su destino. La tierra y los instrumentos de producción y de cambio deben estar socializados.

Los elementos culturales y los capitales socializados deben concurrir a la producción en la forma que el Estado por medio de sus órganos establezca, según procedimientos encaminados a obtener el mayor rendimiento posible a costa del más ínfimo esfuerzo.

La distribución de los productos corresponde igualmente al Estado por medio de sus órganos. Debe asegurarse a cada persona lo necesario para la vida y para su desarrollo integral.

El producto excedente se destinará al bienestar general y al fomento de las ciencias y de las artes.

La República de Chile será federal.

El Gobierno de la República, de los Estados federales y de las comunas se organizará con arreglo al principio del sistema colegiado.

El Poder Legislativo de la República y de los Estados residirá en Cámaras funcionales, compuestas por representantes elegidos por los gremios organizados del país. El mandato de estos representantes será siempre revocable.

El Tribunal Supremo federal de Justicia será elegido por los gremios organizados y sus funciones serán temporales.

Se procederá a la absoluta separación de la Iglesia y el Estado. 
La finalidad de la enseñanza es capacitar al hombre para bastarse a sí mismo económicamente y darle una cultura desinteresada que lo dignifique y lo haga amar y comprender la verdad, el bien y la belleza.

El Estado debe proporcionar los fondos para la enseñanza pública, que debe ser gratuita desde la escuela primaria hasta la Universidad.

A los consejos de maestros, padres y estudiantes corresponden la plena dirección de la enseñanza.

La única intervención del Estado en la enseñanza pública debe ser la de proporcionarle los fondos para que esta realice sus fines propios y la de ejercer el control de la capacidad técnica de los educadores, respetando en forma absoluta la libertad de la cátedra y el espíritu del magisterio.

Debe declararse la igualdad de derechos políticos y civiles de ambos sexos.

Debe suprimirse el ejército permanente.

Todos los funcionarios del Estado deben tener responsabilidad efectiva y no simplemente nominal" ${ }^{118}$.

Lo más novedoso y significativo de este programa era el proyecto de un Estado federal, al servicio de las tareas productivas y del bienestar de las grandes mayorías nacionales. Innovadora también era la propuesta de hacer residir el Poder Legislativo en "cámaras funcionales", esto es, de base gremial, cuyos miembros serían revocables. De manera congruente con estos principios, la Asamblea Constituyente debía "generarse con representantes de todas las fuerzas vivas de ambos sexos", teniendo los asalariados una mayoría asignada con anterioridad. Cabe resaltar que el plan de representación corporativa de la sociedad -resistida por algunos sectores de la "Constituyente Chica" y apoyada con fervor por los comunistas- significaba una ruptura de grandes proporciones con el principio democrático liberal "un hombre un voto" o "una persona un voto" como recién algunos lo preconizaban en Chile. Aunque sus fuentes no están claras, podemos estimar que se emparentaba en alguna medida con las ideas corporativistas que estaban de moda por aquellos años en el Viejo Continente. Se trataba, a todas luces, de una victoria de la política comunista puesto que esta proposición había sido formulada -como está dicho- por el PCCh poco después del golpe de Estado de septiembre de 1924. A los días de clausurada la Asamblea Constituyente de Asalariados e Intelectuales, los activistas de este partido proclamaron su triunfo explicando el sentido de las cámaras de base gremial:

La Cámara Funcional a base gremial significa la muerte de los partidos políticos históricos y con ello los intereses de círculos y los privilegios de clase que desaparecerán con el advenimiento al poder del proletariado generado en los

\footnotetext{
118 "Principios constitucionales de la República de Chile aprobados por la Asamblea Constituyente de Obreros e Intelectuales", Justicia, Santiago, 14 de marzo de 1925. Este documento también fue publicado, entre otros, en "Ecos del Congreso Constituyente de Asalariados e Intelectuales", El Mercurio, Santiago, 13 de marzo de 1925; "Principios aprobados por la Constituyente Chica. Lo que debe ser la futura Constitución política de Chile", El Despertar de los Trabajadores, Iquique, 31 de marzo de 1925; "Principios porque debe luchar el proletariado en las elecciones para la Constituyente. Aprobados en el Congreso de Asalariados e Intelectuales celebrado en Santiago el 8 de Marzo de 1925", La Jornada Comunista, Valdivia, 4 de junio de 1925.
} 
sindicatos industriales y gremios de todas las actividades de cuyo seno saldrán los hombres que regirán los destinos de la nueva sociedad.

Por esta razón, al ser aprobada la Cámara Funcional con el optimismo propio de nuestras convicciones acariciamos la esperanza próxima a realizarse de obtener la victoria de capital importancia: la socialización de la tierra. Y nuestro triunfo que es el triunfo de los oprimidos, fue completo en el memorable Congreso de Asalariados. La abolición de la Cámara política de cuyo seno salen los Ministerios de Estado que forman el Gobierno, los que hasta hoy han oprimido a los habitantes para defender intereses creados de la actual sociedad capitalista que representan, importa en sí el reconocimiento de lo infame y desconcertante que es este régimen inicuo que soportamos, basado en los irritantes privilegios de una clase dominante que siendo dueña y señora de la tierra, dispone a su antojo del bienestar y la vida misma de todo un pueblo que lucha por romper sus cadenas.

Si el poder de la clase opresora, tiene por baluarte el Estado, con sus órganos opresores, el Poder Legislativo, Ejecutivo y Judicial y estos poderes son de origen y constitución política; y los partidos políticos son los que mantienen el régimen capitalista, la Cámara Funcional a base gremial, que representa la inmensa mayoría del país, sometidos a la esclavitud económica significa la transformación del actual régimen social, como consecuencia lógica del cambio básico que determina la destrucción del instrumento opresor del capitalismo, con la creación del nuevo sistema de generación de los poderes públicos por los elementos del proletariado.

Si ninguna fuerza coercitiva impidiera el libre y natural desarrollo de la Cámara Funcional, aún, no existiendo la socialización de la tierra, su acción tendería a establecer los principios fundamentales de justicia social y la abolición de la propiedad privada, sería decretada. Porque dominarán en ella, los representantes del proletariado, por gran mayoría, como dominan hasta hoy, las fuerzas opresoras de la burguesía por medio de las Cámaras políticas ${ }^{119}$.

Desde esta perspectiva, la Cámara Funcional sería un sistema capaz de destruir, desde sus raíces, todos los intereses creados y privilegios de castas, único procedimiento para nivelar todos los derechos que disminuirían las odiosas desigualdades. Recién entonces, desaparecida la causa de todas las desgracias del pueblo al extinguirse el aparato político opresor de la oligarquía y burguesía en general, empezaría la era de justicia y armonía social. La técnica de la producción y el consumo controlados por los productores y peritos profesionales, se perfeccionaría gradualmente y desaparecerían la miseria, la ignorancia y la maldad. La Cámara Funcional a base gremial, sería el "antídoto de las Cámaras políticas mantenedoras de la esclavitud y los sufrimientos del proletariado", "el sistema salvador" que liberaría al pueblo de Chile de los parásitos sociales ${ }^{120}$.

No es necesario adscribir a una visión ortodoxa y rígida del marxismo para percatarse de la dosis de ingenuidad de estas formulaciones. Chile no se hallaba a las puertas de la revolución social. Si bien existía un clima de agitación y el sistema parlamentarista había colapsado bajo la presión combinada de la crisis económica, los movimientos sociales y el Ejército, la clase dominante tenía aún buenas cartas en su mano,

\footnotetext{
${ }^{119}$ Manuel A. Silva R., "El Congreso de los asalariados y los debates doctrinarios. La Cámara funcional a base gremial", Justicia, Santiago, 22 de marzo de 1925.

${ }^{120}$ Ibid.
} 
siendo la principal de ellas el propio Alessandri Palma cuyo retorno al país se produciría pocos días después del término de los debates de la "Constituyente Chica". Pensar, por otra parte, que el cambio podía llevarse a cabo en su totalidad con un proceder totalmente pacífico, sin más ejercicio de la fuerza que la libre expresión del "poder constituyente" de los asalariados y de aquellos intelectuales dispuestos a ser sus aliados, es replicar las ilusiones de algunos de los protagonistas del ejercicio deliberativo del movimiento popular y de los partidos de izquierda y de centro izquierda que participaron en su génesis y desarrollo.

Lo anterior no invalida la legitimidad y valor de esta experiencia. Proposiciones como plena igualdad entre hombres y mujeres, supresión del ejército permanente (aunque sin indicación acerca del organismo o del procedimiento en que la sociedad asumiría su reemplazo), completa separación de la Iglesia y el Estado, del mismo modo que la declaración de la tierra como "propiedad social en su origen y en su destino", por ende su socialización al igual que "los instrumentos de producción y de cambio" a fin de concurrir con "los elementos culturales" y los capitales también socializados a la producción en la forma que el Estado por medio de sus órganos estableciera, eran elementos de un avanzado programa de transformación social, tan avanzado que, incluso, un siglo más tarde no ha sido realizado. Todos estos puntos coincidían a la perfección con el programa -táctico y estratégico- comunista, pero solo en parte con el de otros componentes de la "Constituyente Chica”, lo que explica muchas de las tensiones que generó su discusión y aprobación, asimismo el notorio desapego de los "compañeros de ruta" del comunismo chileno hacia estos acuerdos. Las propuestas sobre la cuestión educacional reflejaron el frágil compromiso alcanzado luego de acalorados debates al proclamar que el único deber del Estado consistiría en aportar los recursos y ejercer la supervisión de la capacidad técnica de los educadores, instaurándose una suerte de lo que mucho tiempo después otros actores denominarían "control comunitario", a través de la dirección de la educación por los consejos de maestros, padres y estudiantes. Este era el único punto de los lineamientos constitucionales del bloque de obreros, trabajadores "de cuello y corbata" e intelectualidad crítica, que se apartaba un tanto de las formulaciones tradicionales comunistas, reflejando las concesiones que estos habían hecho a sus aliados circunstanciales de la Asociación General de Profesores para evitar un desenlace aún más traumático de la convención de marzo.

En todo caso, los porfiados hechos demostrarían con prontitud que esta deliberación constitucional no contaba con la correlación de fuerzas necesaria para imponer su sello al proceso constituyente. Este se realizaría -como expondremos de traza sucinta- de acuerdo a los designios de Alessandri y sus hombres de confianza.

\section{El proceso constituyente que fue}

Los laboriosos acuerdos de la Asamblea Constituyente de Asalariados e Intelectuales no tuvieron trascendencia práctica alguna en la coyuntura política chilena de 1925; a los pocos días eran letra muerta. Apenas se disolvió la asamblea, cada fuerza política siguió su propio camino porque los consensos logrados eran menos profundos que sus diferencias. La práctica demostró con prontitud que la persistencia de una iniciativa 
común respecto de la cuestión constitucional era una utopía. Radicales y demócratas se consagraron a tratar de incidir en el proceso constituyente impulsado por Alessandri, olvidando sin más ni más lo decidido en la "Constituyente Chica". Los anarquistas, que hacia 1925 ya habían ingresado en un prolongado ciclo de divisiones y de declive, no estaban en condiciones de impulsar ninguna política unitaria, ni siquiera en el seno de su propio campo $^{121}$. Los maestros, empleados y gremios no afiliados a alguna corriente ideológica, no irradiaban mucho más allá de su propio sector corporativo. La Asociación General de Profesores, quizás el organismo gremial (sin claros vínculos partidistas) más inclinado a incursionar en la arena política, se concentró en su lucha por la reforma educacional, formulando algunos planteamientos interesantes, mas desligados de la cuestión constitucional $^{122}$. La Unión de Empleados de Chile se abocó a fortalecerse orgánicamente, a preparar su segundo congreso y a conseguir su reconocimiento oficial por el gobierno mediante la aprobación de sus estatutos y la concesión de personería jurídica apoyándose en los buenos oficios del oligarca liberal Eleodoro Yáñez ${ }^{123}$. Los círculos dirigentes de la $\mathrm{FECH}$, por su parte, realizaron un balance lapidario del ejercicio constituyente de marzo. Según un artículo publicado en Claridad, órgano oficial de la institución estudiantil:

Las grandes expectativas que se cifraban en el Congreso Constituyente de Asalariados e Intelectuales resultaron completamente fallidas.

Contrariamente a lo que todos esperaban, no se consideró en esa heterogénea reunión de hombres movidos por pasiones pequeñas y ambiciones deleznables, una sola cuestión de positivo y verdadero interés para los trabajadores.

Todo estuvo limitado a las declamaciones huecas a que nos tienen acostumbrados los políticos profesionales y los oradores federados de mítines callejeros.

Los dirigentes socialdemócratas, que aquí como en otras partes se llaman comunistas, se dedicaron a hacer retruécanos más o menos pintorescos sobre la 'dictadura del proletariado', y a aprobar mediante el apoyo de una mayoría ocasional y mecanizada, principios reformistas patrocinados por el señor Óscar Fontecilla, el más destacado oportunista que hayamos conocido.

Las pocas voces que salieron en defensa de las ideas libertarias, se vieron acalladas por el sectarismo de los feligreses que, a pesar de todos los fracasos experimentados, continúan rindiendo culto a los desacreditados pontífices del marxismo moscovita.

\footnotetext{
${ }^{121}$ Como se indicó, solo algunos sectores ácratas participaron en la "Constituyente Chica", otros -como la FOI- se automarginaron, debilitando la presencia anarquista en este evento. Así, por ejemplo, una propuesta de destrucción del Estado y creación de una libre federación de productores fue rechazada por los delegados, siendo criticada incluso por otros sectores libertarios. Víctor Muñoz Cortés, Sin Dios ni patrones. Historia, diversidad y conflictos del anarquismo en la región chilena (1890-1990), Valparaíso, Mar y Tierra Ediciones, 2013, pág. 46. Sobre el inicio de la decadencia de la corriente ácrata en Chile, véase Bastías, op. cit., págs. 54-58.

${ }^{122}$ Juan de la C. Matus, "Abramos paso a la reforma de la enseñanza" y Víctor Troncoso M., "La Reforma Educacional ante la opinión pública", Nuevos Rumbos, $\mathrm{N}^{\circ} 132$, Santiago, 18 de abril de 1925, págs. 3 y 9 respectivamente; "El gran comicio simultáneo pro reconstrucción de la enseñanza", Nuevos Rumbos, $\mathrm{N}^{\circ} 132$, Santiago, 1 de mayo de 1925, pág. 9.

${ }^{123}$ Francisco Hinojosa Robles, El libro de oro de los empleados particulares, Santiago, Editorial Nascimento, 1967, págs. 165-168.
} 
En ningún momento fue posible una discusión serena y elevada sobre el problema social, que no tuviera como base la aceptación de los postulados del bolchevismo militante. Un concilio, una asamblea de inquisidores negándose a escuchar a los heréticos que pusieran en duda la existencia de la divinidad, no habría demostrado un mayor espíritu de intransigencia e intolerancia" ${ }^{124}$.

En este contexto, solo el PCCh y la FOCH continuaron sosteniendo de manera sistemática los acuerdos mayoritarios porque casi todos ellos coincidían con sus propios planteamientos. Así, recién secada la tinta del documento final de la "Constituyente Chica", demócratas, radicales y empleados se aprestaron a concurrir en una Convención de la Juventud de los Partidos de Avanzada (de signo liberal progresista) mientras que el PCCh cuya dirección se negó a participar en este evento- y la FOCH se dedicaban a difundir en su base social los acuerdos -cada vez más ficticios- contraídos. De este modo, a escasos días de la inauguración de la Convención de las Juventudes de Avanzada, el Centro "El Despertar" de la capital invitó a los trabajadores a una reunión en la que Carlos Contreras Labarca, Luis Víctor Cruz, Salvador Barra Woll, Manuel Hidalgo y otros dirigentes explicarían las principales materias tratadas en la reciente deliberación popular, dando "a conocer la orientación definida que le corresponde a las clases trabajadoras frente a estos problemas" 125 .

Alessandri Palma desechó rápidamente su promesa de convocatoria a una Asamblea Constituyente alegando "falta material de tiempo para verificar las inscripciones del electorado, para instalar enseguida la Constituyente y para que esta dispusiera del tiempo necesario para terminar su misión y alcanzar a fijar las reglas de la elección del Congreso y del Presidente" que debía sucederlo el 23 de diciembre de ese mismo año ${ }^{126}$. Pocas semanas después de reasumir la presidencia de la República, “el León” por sí y ante sí, designó a los miembros de las dos comisiones que debían preparar la Asamblea Constituyente, escogiendo a una mayoría de políticos tradicionales, incluyendo entre ellos a Luis Barros Borgoño, su rival en la elección de 1920. Uno que otro dirigente de la "Constituyente Chica" -los comunistas Carlos Contreras Labarca, Luis Víctor Cruz y Manuel Hidalgo, los de mócrat a s Onofre Avendaño y Fernando García Oldini, y el líder mutualista Carlos Alberto Martínez- fue invitado a participar en las discusiones ${ }^{127}$. El propio Alessandri presidió la "comisión chica" que debía estudiar las reformas constitucionales y Arturo Lyon quedó a la cabeza de la "comisión grande" encargada de preparar la convocación a la Asamblea

\footnotetext{
124 "Plaga de Convenciones. La Convención de Asalariados”, Claridad, N¹30, Santiago, mayo de 1925.

125 "Las resoluciones de la Constituyente Chica y los deberes del proletariado", Los Tiempos, Santiago, 18 de marzo de 1925.

${ }^{126}$ Arturo Alessandri Palma, Recuerdos de gobierno, Santiago, Editorial Nascimento, 1967, tomo II, pág. 173. Sobre las razones que motivaron el cambio de posición de Alessandri respecto de la forma como debía gestarse la nueva Constitución, véase también, Vial, op. cit., vol. III, págs. 532-536.

127 Alessandri, op. cit., tomo II, págs. 157-163; Vial, op. cit., vol. III, págs. 536 y 537. Es necesario precisar que el único miembro de la "Constituyente chica” que, a su vez, participó en la única comisión gubernamental constituyente que funcionó en 1925, fue el comunista Manuel Hidalgo.
} 
Constituyente. Este grupo -lo dejó consignado el "León de Tarapacá" en sus Recuerdos de gobierno- no se reunió o, a lo sumo, lo hizo una vez ${ }^{128}$.

En la "comisión chica" se enfrentaron tres proposiciones para aprobar la nueva Constitución: elección de una Asamblea Constituyente mediante sufragio universal; organización de una Constituyente sobre una base gremial o ratificación del texto preparado por la comisión mediante un plebiscito ${ }^{129}$. Intuyendo que su proyecto de Constitución presidencialista no sería aprobado en una Asamblea Constituyente dominada por los partidos tradicionales, muy reticentes a abandonar el sistema parlamentario, Alessandri apostó a la vía más expedita convirtiendo a la "comisión chica" en la Constituyente misma y utilizó toda su capacidad de maniobra, influencia y poder para vencer las diversas resistencias que suscitaba su plan, tanto entre muchos personajes de la vieja elite política proclives al sistema parlamentario como en el movimiento obrero y popular partidario de la Constituyente de base gremial.

En treinta y tres sesiones realizadas durante cuatro meses a las que asistió un promedio de doce personas, la "comisión chica" preparó el proyecto de Constitución propiciada por el Jefe de Estado. Los debates se centraron, de preferencia, en el modo como equilibrar los poderes Ejecutivo y Legislativo, de acuerdo con la perspectiva liberal. El único invitado de la Asamblea de Asalariados e Intelectuales a esta instancia, el comunista Manuel Hidalgo, quedó aislado ${ }^{130}$. Aunque ajena al proceso constituyente, la feroz represión al movimiento obrero perpetrada a comienzos de junio por el Ejército en la oficina salitrera tarapaqueña de La Coruña ${ }^{131}$, fue determinante y marcó los límites que el binomio conformado por el Presidente de la República y su ministro de Guerra Carlos Ibáñez de Campo le fijaron al movimiento de trabajadores. Las posibilidades de acción de este se vieron reducidas al mínimo. A la postre, la fuerza militar inclinó la balanza en el seno de la Comisión Constituyente. A partir del 23 de julio, el Inspector General del Ejército general Navarrete apoyó abiertamente las proposiciones de Alessandri de Constitución presidencialista y plebiscito como fórmula de aprobación ${ }^{132}$. De esta manera, Alessandri consiguió imponer la vía plebiscitaria en vez de la convocatoria a una Asamblea Constituyente que implicaba un verdadero debate constitucional nacional.

El plebiscito fue convocado con apenas un mes de anticipación para el 30 de agosto. Los electores deberían optar entre tres cédulas de voto: una roja, de aprobación del proyecto de la mayoría de la "comisión constituyente" armada por el

\footnotetext{
${ }^{128}$ Alessandri, op. cit., tomo II, pág. 173.

${ }^{129}$ Ibid., tomo II, págs. 177 y 178.

${ }^{130}$ Ministerio del Interior, Actas oficiales de las Sesiones celebradas por la Comisión y Sub-comisiones encargadas del estudio del Proyecto de nueva Constitución Política de la República, Santiago, Imprenta Universitaria, 1925. Véase también, Felipe Portales, Los mitos de la democracia chilena, vol. II. Desde 1925 a 1938, Santiago, Catalonia, 2010, 34-39; Alessandri, op. cit., tomo II, págs. 189-242.

131 Sobre esta matanza, véase, entre otros, Rolando Álvarez Vallejos, "La matanza de Coruña", en Contribuciones Científicas y Tecnológicas, No 116, Santiago, USACH, 1997, págs. 77-108; Alberto Harambour Ross, "Ya no con las manos vacías. (Huelga y sangre obrera en Alto San Antonio. Los 'sucesos' de La Coruña. Junio de 1925)", en Pablo Artaza et al., A noventa años de los sucesos de la Escuela Santa María de Iquique, Santiago, DIBAM - Lom Ediciones - Universidad Arturo Prat, 1998, págs. 183-192.

${ }^{132}$ Alessandri, op. cit., tomo II, págs. 228 y 229; Vial, op. cit., vol. III, págs. 539-546.
} 
gobierno; una azul, obra de los disidentes (radicales, conservadores y comunistas), que conllevaba la aprobación de una serie de propuestas destinadas a recortar el poder del Ejecutivo (como la posibilidad de que el Congreso acusara y destituyera al Presidente) y una blanca, que significaría "buscar otros procedimientos para restablecer la normalidad institucional del país"133. Los opositores insistieron en la amenaza implícita de esta última fórmula que insinuaba, casi sin disimulo, una nueva intervención militar. Asimismo criticaron el reducido plazo - un mes- para hacer campaña, además del hostigamiento y represión policiales a sus mítines. Las organizaciones sociales escogieron caminos divergentes, según las influencias ideológicas prevalecientes en cada una de ellas: algunas, como las anarcosindicalistas, preconizaron la abstención; otras cercanas al Partido Democrático- la cédula roja; las afiliadas a la FOCH, controladas por el PCCh, se inclinaron naturalmente por la cédula azul. La Unión de Empleados de Chile dio un paso importante en la recomposición de las buenas relaciones que había sostenido con el PCCh y la FOCH antes de la "Constituyente Chica" (momento en el que se enfrentó a comunistas y fochistas a propósito de la cuestión educacional), al llamar también votar por la cédula azul ${ }^{134}$.

El proyecto de Constitución impulsado por Alessandri fue aprobado por una minoría de electores. Sobre 302.304 inscritos solo votaron 135.783, de los cuales 127.509, o sea, 42,18\% de los inscritos y 93,9\% de los votantes aprobaron el proyecto del Presidente de la República. La alternativa de los partidos opositores (cédula azul) obtuvo 6.825 votos $(2,26 \%$ de los inscritos y $5,03 \%$ de los sufragios), la cédula blanca (la incierta búsqueda de "otros procedimientos") reunió 1.449 preferencias $(0,48 \% \text { de los inscritos y } 1,07 \% \text { de los votos })^{135}$.

\section{Conclusión}

Si bien la Asamblea Constituyente de Asalariados e Intelectuales representó un esfuerzo significativo de un importante sector del movimiento popular por dotarse de lineamientos programáticos que pesaran en el proceso constituyente de 1925, en la práctica no tuvo la menor incidencia en aquella coyuntura. Sus dificultosos acuerdos fueron la expresión máxima de convergencia táctica que podía existir entre socios tan disímiles como comunistas, fochistas, anarquistas, radicales, demócratas, feministas, intelectuales críticos, mutualistas y sindicalistas independientes. Las bases de esta entente eran frágiles, más aparentes que reales. Es probable que esta sea la causa principal de su derrota, expresión, en definitiva, de las debilidades de este movimiento. Cuando Alessandri Palma fue recibido de manera apoteósica en Santiago el 20 de marzo, los socios de la "Constituyente Chica" ya habían retomado sus respectivos caminos y no tenían ni la pujanza ni la disposición de actuar unidos para defender el programa que venían de aprobar. Solo el PCCh y la FOCH

\footnotetext{
133 Alessandri, op. cit., tomo II, págs. 235 y 236.

${ }^{134}$ Aldo Cofré Arredondo, “'Trabajadores de cuello y corbata'. Identidad, asociatividad y acción colectiva en el movimiento de empleados particulares. Chile, 1918-1925”, informe final para optar al grado de Licenciado en Historia, Santiago, Universidad de Chile, 2011, págs. 118 y 119.

${ }^{135}$ Vial, op. cit., vol. III, pág. 548.
} 
continuaron agitándolo durante un breve lapso porque, como está dicho, coincidía con lo esencial de su política para esa coyuntura.

Las fuerzas motrices de esta experiencia no tardaron en comprender que su proyecto no era viable y reorientaron sus esfuerzos en función de las exigencias del nuevo contexto que generó la victoria del proyecto constitucional de "el León". La asamblea popular de marzo de 1925 quedó como un lejano recuerdo, lejano no por el transcurrir del tiempo, sino por su vertiginosa obsolescencia política. La derrota de la "Constituyente Chica" no fue épica, por el contrario, fue prosaica, como tantas otras que, a diferencia de las derrotas épicas, nadie reivindica, no dejan huella, no fundan leyenda ni forjan identidad.

Esta mentada asamblea puede ser considerada un ejemplo de olvido constituyente por parte de sus promotores: ni acabó en un baño de sangre, ni generó odiosidades o rivalidades mayores que las que ya existían entre sus protagonistas (puesto que pocos meses más tarde una buena parte de ellos confluyó en un nuevo frente de "asalariados" para presentar una candidatura presidencial, la del médico José Santos Salas). Naturalmente fue relegada por sus propios actores y sus herederos políticos al espacio siempre frágil de la memoria individual, tal vez porque la consideraron intrascendente, un error a no volver a repetir o un hecho menor de su propia historia.

Aunque este confinamiento por sus progenitores en el escenario político de mediados de la década de 1920 es de fácil comprensión -porque la rápida evolución de la situación dejó casi de inmediato obsoletos los laboriosos acuerdos de la "Constituyente Chica", empujando a todos los protagonistas a dar respuestas en el cambiante cuadro generado por las acciones de los políticos de la clase dominante- resulta más difícil entender el silencio o la minimización extrema en el que incurrieron los memorialistas, biógrafos, cronistas, historiadores y otros sujetos representativos de las fuerzas que impulsaron dicho ejercicio. Connotados activistas comunistas que a continuación ocuparían los más altos cargos en su partido, como Elías Lafertte, Juan Chacón y Víctor Contreras Tapia, contemporáneos de la Asamblea Constituyente de Asalariados e Intelectuales, ni siquiera la mencionaron en sus memorias escritas o dictadas décadas más tarde ${ }^{136}$. Tampoco la nombraron los manuales o cartillas para la educación de la militancia que se refirieron de manera particular a la historia del partido ${ }^{137}$. Tal vez ello se deba a la traumática "bolchevización" sufrida por el PCCh ante la inducción de la Internacional Comunista entre 1927 y 1933, que condenó muchos aspectos de la política "recabarreana" como "desviaciones" de "izquierda" o de "derecha". A pesar de que desde mediados de la década de 1930 el PCCh hizo marcha atrás en algunos puntos, volviendo a reivindicar el legado político de su principal líder después de haberlo reprobado, no cabe duda que muchos aspectos de la "bolchevización" quedaron incorporados a la cultura y la línea de este partido $^{138}$. Cuestión que queda notoriamente reflejada en los juicios de su historiador “oficial” Hernán Ramírez Necochea.

\footnotetext{
${ }^{136}$ Elías Lafertte, Vida de un comunista, Santiago, Empresa Editora Austral, 1971, 2ª edición; José Miguel Varas, Chacón, Impresora Horizonte Ltda., 1968; Víctor Contreras Tapia, Campesino y proletario, Moscú, Editorial de la Agencia de Prensa Nóvosti, 1981.

${ }^{137}$ Véase a modo de ejemplo, José González, Curso elemental sobre el partido. Partido Comunista de Chile, $2^{a}$ edición, sin indicación de ciudad ni editorial, 1964.

138 Sobre la "bolchevización" impuesta al PCCh por la Internacional Comunista, véanse, entre otros, Olga Ulianova, "El Partido Comunista chileno durante la dictadura de Carlos Ibáñez (1927-1931): primera
} 
Para radicales, demócratas y anarquistas la "Constituyente Chica" fue siempre un hecho menor que no concitó -a diferencia de los comunistas- una postura común en el seno de sus corrientes o formaciones políticas. Carlos Vicuña Fuentes, dirigente del Comité Nacional Obrero, no la reivindicaría en sus memorias, evocándola -sin la menor mención a su propio rol- solo una vez, ambigua y tangencialmente, "a la pasada", al referirse al proceso constituyente de 1925:

La opinión cuchicheaba contra Alessandri, el Pueblo se agitaba. Una Convención de Asalariados había venteado una serie de doctrinas revolucionarias, otra de Estudiantes, Intelectuales y Obreros había hecho lo propio. El Congreso continuaba cerrado y los políticos se agitaban para pedir su reapertura. Otros la estimaban improcedente en vista de que debería convocarse una Constituyente. Pero la Constituyente tampoco venía ${ }^{139}$.

Por su parte, otros actores relevantes omitieron esta gran reunión de sus recuerdos públicos. De esta suerte lo hizo, por ejemplo, ni más ni menos, que Manuel Hidalgo, presidente del Comité Nacional Obrero, quien al ser entrevistado cuatro décadas más tarde por el periodista Wilfredo Mayorga, no se refirió al suceso. Aunque podría alegarse que el periodista no lo interrogó sobre el proceso constituyente de 1925, no es menos cierto que el tipo de preguntas -sobre el $\mathrm{PCCh}$, la $\mathrm{FOCH}$, Alessandri, etc.- hubiese permitido que Hidalgo se refiriera a la "Constituyente Chica", así fuera de soslayo ${ }^{140}$.

En el caso de la mayoría de los historiadores del período que la omitieron o apenas la mencionaron, podría aplicarse el concepto de olvido excluyente, aquel que conlleva la intención de reprimir un contenido para controlarlo y arrojar fuera del mundo de lo decible aquello que de ningún modo puede ser asumido. Los sujetos populares deliberando a fin de erigirse en titulares de la soberanía es un fenómeno que escapa a los parámetros de la historiografía tradicional, ya sea conservadora o liberal. También puede ser un terreno de

clandestinidad y 'bolchevización' estaliniana”, en Boletín de la Academia Chilena de la Historia, $\mathrm{N}^{\circ} 111$, Santiago, 2002, págs. 385-436; Olga Ulianova, "Develando un mito: emisarios de la Internacional Comunista en Chile", en Historia, N41, vol. I, Santiago, enero-junio de 2008, pp. 118-121; Mariano Vega Jara, “¿Hidalguismo versus laferttismo? Crisis y disputa por la representación del comunismo en Chile, 19291933”, en Olga Ulianova, Manuel Loyola y Rolando Álvarez (editores), 1912-2012. El siglo de los comunistas chilenos, Santiago, Universidad de Santiago de Chile, Instituto de Estudios Avanzados, 2012., págs. 97-169; Gabriel Muñoz Carrillo, "Disputa por el comunismo en Chile. Estalinistas y oposicionistas en el partido de Recabarren (1924-1934)", informe de seminario de grado para optar al grado de Licenciado en Historia, Santiago, Universidad de Chile, 2014; Sergio Grez Toso, "Un episodio de las políticas del 'Tercer Período' de la Internacional Comunista: elecciones presidenciales en Chile, 1931”, en Historia, vol. 48, №2, Santiago, diciembre de 2015, págs. 465-503; Ximena Urtubia Odekerken, "Hegemonía y cultura política del Partido Comunista de Chile: del militante tradicional al de la nueva época, 1924-1933", informe de seminario de grado para optar al grado de Licenciada en Historia, Santiago, Universidad de Chile, 2015.

139 Carlos Vicuña, La tiranía en Chile: libro escrito en el destierro en 1928, Santiago, Lom Ediciones, 2002, pág. 311.

140 "Todos bailábamos el año veinte", entrevista de Wilfredo Mayorga a Manuel Hidalgo Plaza publicada por primera vez en revista Ercilla, Santiago, 21 de abril de 1965. Reproducida en Rafael Sagredo Baeza (recopilador), Crónicas políticas de Wilfredo Mayorga. Del “Cielito Lindo” a la Patria Joven, Santiago, Dirección de Bibliotecas, Archivos y Museos - Ediciones RIL - Centro de Investigaciones Diego Barros Arana, 1998, págs. 43-50. 
silenciamiento y olvido excluyente de historiografías postmodernas de diverso signo ideológico, pero coincidentes en su desdén por el estudio de las tentativas de "los de abajo" por instalar un "gran relato" en forma de proyecto de sociedad.

No resulta insólito entonces que desde la otra vereda del conflicto social y de la producción historiográfica, un historiador como Gabriel Salazar haya rescatado este suceso convirtiéndolo en un paradigma del "poder constituyente de las bases sociales", de acuerdo con sus concepciones políticas e historiográficas, refractarias a reconocer el estrecho vínculo que ha existido a lo largo de la historia republicana de Chile entre los movimientos sociales y la política partidista. Sin embargo, tal como hemos demostrado en este artículo, la "Constituyente Chica" no fue una excepción a una constante histórica de este país ya que sus avatares, fortalezas y debilidades se derivaron, en gran medida, de la relación dialéctica entre las fuerzas políticas y corrientes ideológicas que concurrieron y se confrontaron en su seno, no de la supuesta acción autónoma y espontánea de "bases sociales" autoconvocadas. Las fuentes de época consultadas no dejan lugar a la menor duda al respecto. Parafraseando la crítica del historiador Manuel Loyola, podría afirmarse en esta materia que el ejercicio consistente en "escamotear buena parte de la politicidad popular, por corresponder a lo articulado por la izquierda tradicional", no es sino una nueva mitificación de la historia, que no logra dar cuenta de este y otros fracasos de los movimientos populares más allá de la alusión ya ritual a la maldad de los poderosos y los falsos amigos del pueblo ${ }^{141}$. Lo que viene a reafirmar, de paso, que la búsqueda de los deseos del presente en el pasado, sigue siendo uno de los mayores riesgos que acechan a los historiadores ${ }^{142}$.

Como bien señalara Hobsbawm al indicarnos que la historia de la identidad no es suficiente, "la deconstrucción de mitos políticos disfrazados de historia forma parte desde hace tiempo de las obligaciones profesionales del historiador, con independencia de sus simpatías" ${ }^{\text {"143 }}$. La historia de la Asamblea Constituyente de Asalariados e Intelectuales nos ofrece una buena oportunidad para hacerlo.

\section{Bibliografía}

Alessandri Palma, Arturo, Recuerdos de gobierno, Santiago, Editorial Nascimento, 1967, tomo II.

Álvarez Vallejos, Rolando, "La matanza de Coruña”, en Contribuciones Científicas y Tecnológicas, No 116, Santiago, USACH, 1997, págs. 77-108.

Barnard, Andrew, The Chilean Communist Party, 1922-1947, thesis present for the degree of Doctor of Philosophy in the University of London, London, University College, University of London, december 1977.

Bastías, Ignacio, "Política libertaria y movimiento anarquista en Santiago, 1917-1927”, Tesis para obtener el grado de Licenciado en Historia, Santiago, Universidad de Chile, 2007.

\footnotetext{
${ }^{141}$ Loyola, op. cit., pág. 183-185.

142 Hobsbawm, op. cit., pág. 273.

${ }^{143}$ Ibid.
} 
Bermejo Barrera, José Carlos, "La Historia, la memoria y el olvido", en José Carlos Bermejo Barrera y Pedro Andrés Piedras Monroy, Genealogía de la Historia. Ensayos de Historia Teórica III, Madrid, Ediciones Akal, 1999.

Biblioteca del Congreso Nacional, Historia Política Legislativa del Congreso Nacional de Chile, http://historiapolitica.bcn.cl/resenas_parlamentarias/wiki/

Cofré Arredondo, Aldo, “'Trabajadores de cuello y corbata'. Identidad, asociatividad y acción colectiva en el movimiento de empleados particulares. Chile, 1918-1925", informe final para optar al Grado de Licenciado en Historia, Santiago, Universidad de Chile, 2011.

Contador, Ana María, "La Asociación General de Profesores de Chile: 1922-1928”, tesis para optar al grado de Licenciada en Historia, Santiago, Universidad de Chile, 1986.

Contreras Tapia, Víctor, Campesino y proletario, Moscú, Editorial de la Agencia de Prensa Nóvosti, 1981.

De Ramón, Armando, Biografías de Chilenos. Miembros de los poderes Ejecutivo, Legislativo y Judicial 1876-1973, vol. I, Santiago, Ediciones Universidad Católica de Chile, 1999, pág. 118.

Díaz, José, Militares y socialistas en los años veinte. Orígenes de una relación compleja, Santiago, Universidad ARCIS, 2002.

Fontana, Josep, La historia de los hombres: el siglo XX, Barcelona, Crítica, 2002.

González, José, Curso elemental sobre el partido. Partido Comunista de Chile, $2^{\text {a }}$ edición, sin indicación de ciudad ni editorial, 1964.

Grez Toso, Sergio, "Escribir la historia de los sectores populares. ¿Con o sin la política incluida? A propósito de dos miradas a la historia social (Chile, siglo XIX)", en Política, vol. 44, Santiago, Otoño de 2005, págs. 17-31.

Grez Toso, Sergio, Historia del comunismo en Chile. La era de Recabarren, 1912-1924, Santiago, Lom Ediciones, 2011.

Grez Toso, Sergio, "La ausencia de un poder constituyente democrático en la historia de Chile", en Grez, Sergio y Foro por la Asamblea Constituyente, Asamblea Constituyente. La alternativa democrática para Chile, Santiago, Editorial América en Movimiento, 2015, págs. 15-49.

Grez Toso, Sergio, "Un episodio de las políticas del 'Tercer Período' de la Internacional Comunista: elecciones presidenciales en Chile, 1931", en Historia, vol. 48, N², Santiago, diciembre de 2015, págs. 465-503.

Grez Toso, Sergio, El Partido Democrático de Chile. Auge y ocaso de una organización política popular (1887-1927), Santiago, Lom Ediciones, 2016. 
Harambour Ross, Alberto, "Ya no con las manos vacías. (Huelga y sangre obrera en Alto San Antonio. Los 'sucesos' de La Coruña. Junio de 1925)", en Pablo Artaza et al., A noventa años de los sucesos de la Escuela Santa María de Iquique, Santiago, DIBAM - Lom Ediciones Universidad Arturo Prat, 1998, págs. 183-192.

Hinojosa Robles, Francisco, El libro de oro de los empleados particulares, Santiago, Editorial Nascimento, 1967.

Hobsbawm, Eric, Sobre la historia, Barcelona, Crítica, 2002.

Lafertte, Elías, Vida de un comunista, Santiago, Empresa Editora Austral, 1971, 2ª edición.

Ljubetic Vargas, Iván, Breve Historia del Partido Comunista, [Santiago], Editorial La Colmena, sin fecha.

Loyola T., Manuel, Reseña del libro publicada en Cuadernos de Historia, №36, Santiago, junio de 2012, págs. 183-185.

Ministerio del Interior, Actas oficiales de las Sesiones celebradas por la Comisión y Sub-comisiones encargadas del estudio del Proyecto de nueva Constitución Política de la República, Santiago, Imprenta Universitaria, 1925.

Miranda, Nicolás, Historia Marxista del Partido Comunista de Chile, Santiago, Ediciones Clase contra Clase, 2001.

Moraga Valle, Fabio, "Muchachos casi silvestres". La Federación de Estudiantes y el movimiento estudiantil chileno 1906-1936, Santiago, Ediciones de la Universidad de Chile, 2007.

Muñoz Carrillo, Gabriel, "Disputa por el comunismo en Chile. Estalinistas y oposicionistas en el partido de Recabarren (1924-1934)", informe de seminario de grado para optar al grado de Licenciado en Historia, Santiago, Universidad de Chile, 2014.

Muñoz C., Víctor M., Armando Triviño: Woobblie. Hombres, ideas y problemas del anarquismo en los años veinte. Vida y escritos de un libertario criollo, Santiago, Editorial Quimantú, 2009.

Muñoz Cortés, Víctor, Sin Dios ni patrones. Historia, diversidad y conflictos del anarquismo en la región chilena (1890-1990), Valparaíso, Mar y Tierra Ediciones, 2013.

Portales, Felipe, Los mitos de la democracia chilena, vol. II. Desde 1925 a 1938, Santiago, Catalonia, 2010.

Ramírez Necochea, Hernán, Origen y formación del Partido Comunista de Chile. Ensayo de historia política y social de Chile, en Hernán Ramírez Necochea, Obras escogidas, vol. II, Santiago, Lom Ediciones, 2007.

Sagredo Baeza, Rafael (recopilador), Crónicas políticas de Wilfredo Mayorga. Del "Cielito Lindo" a la Patria Joven, Santiago, Dirección de Bibliotecas, Archivos y Museos - Ediciones RIL -Centro de Investigaciones Diego Barros Arana, 1998. 
Salazar V., Gabriel, "Movimiento social y construcción de Estado: la Asamblea Constituyente popular de 1925", Documento de Trabajo Nº133, Santiago, SUR, Centro de Estudios Sociales y Educación, 1992.

Salazar V., Gabriel, Del poder constituyente de asalariados e intelectuales (Chile, siglos XX y XXI), Santiago, Lom Ediciones, 2009.

Salazar, Gabriel, En el nombre del poder popular constituyente (Chile, siglo XXI), Santiago, Lom Ediciones, 2011.

Schaff, Adam, Historia y verdad, Barcelona, Editorial Crítica, 1983.

Ulianova, Olga, "El Partido Comunista chileno durante la dictadura de Carlos Ibáñez (1927-1931): primera clandestinidad y 'bolchevización' estaliniana", en Boletín de la Academia Chilena de la Historia, $\mathrm{N}^{\circ} 111$, Santiago, 2002, págs. 385-436.

Ulianova, Olga, "Develando un mito: emisarios de la Internacional Comunista en Chile", en Historia, №41, vol. I, Santiago, enero-junio de 2008, págs. 118-121.

Ulianova, Olga y Alfredo Riquelme Segovia (editores), Chile en los archivos soviéticos 1922-1991, Tomo 1: Komintern y Chile 1922-1931, Santiago, Ediciones de la DIBAM, Centro de Investigaciones Diego Barros Arana - Lom Ediciones, 2005.

Urtubia Odekerken, Ximena, "Hegemonía y cultura política del Partido Comunista de Chile: del militante tradicional al de la nueva época, 1924-1933", informe de seminario de grado para optar al grado de Licenciada en Historia, Santiago, Universidad de Chile, 2015.

Varas, José Miguel, Chacón, Impresora Horizonte Ltda., 1968.

Vega Jara, Mariano, “¿Hidalguismo versus laferttismo? Crisis y disputa por la representación del comunismo en Chile, 1929-1933", en Olga Ulianova, Manuel Loyola y Rolando Álvarez (editores), 1912-2012. El siglo de los comunistas chilenos, Santiago, Universidad de Santiago de Chile, Instituto de Estudios Avanzados, 2012., págs. 97-169.

Vial, Gonzalo, Historia de Chile (1891-1973), vol. III, Arturo Alessandri y los golpes militares (1920-1925), Santiago, Empresa Editora Zig-Zag S.A., 2008.

Vicuña, Carlos, La tiranía en Chile: libro escrito en el destierro en 1928, Santiago, Lom Ediciones, 2002.

Vitale, Luis, Interpretación marxista de la Historia de Chile, tomo V. De la República Parlamentaria a la República Socialista. De la dependencia inglesa a la norteamericana (18911932), Santiago, Lom Ediciones, sin fecha. 


\section{Fuentes primarias}

a) Documentos de archivos

Archivo Nacional de la Administración, Colección Fondos Ministeriales, Ministerio del Interior, Oficios, vol. 6373 (1925)

b) Periódicos

Claridad, Santiago, 1925

Democracia, Santiago, 1902

El Comunista, Antofagasta, 1924-1925

El Despertar de los Trabajadores, Iquique, 1924-1925

El Diario Ilustrado, Santiago, 1924-1925

El Mercurio, Santiago, 1924-1925

El Mercurio, Valparaíso, 1924-1925

El Sur, Concepción, 1924-1925

Justicia, Santiago, 1924-1925

La Jornada Comunista, Valdivia, 1924-1925

La Libertad, Santiago, 1924

La Nación, Santiago, 1924-1925

Las Últimas Noticias, Santiago, 1925

Los Tiempos, Santiago, 1925

Nuevos Rumbos, Santiago, 1925 